\title{
Revision of the genus Hellica Stål, 1867 and the description of three new genera of South American Lanopini (Hemiptera: Acanthosomatidae: Blaudusinae)
}

\author{
Diego L. CARPINTERO \& Sebastián DE BIASE
}

División Entomología, Museo Argentino de Ciencias Naturales "Bernardino Rivadavia” Av. Ángel Gallardo 470. (1405), Ciudad Autónoma de Buenos Aires, Argentina. E-mail: dcarpint@macn.gov.ar; seba.de.biase@gmail.com

\begin{abstract}
Three new genera are described, Epactiohellica based on a new species, E. farinai, Alloeohellica based on another new species A. faundezi, and Hellicoides based on the known species Hellica johni Froeschner. The genus Hellica is redescribed with two known species $H$. nitida Haglund and H. johnpolhemi Froeschner and one new species, H. kolla. Fifth nymphal instar of Hellicoides johni is described for the first time and fifth nymphal instar of $H$. nitida is redescribed. Distributional (biogeography, distributional patterns), ecological (coloration, host plants) and biological characters (nymphs, eggs) of these genera are discussed.
\end{abstract}

Key words: Hemiptera, Acanthosomatidae, New genera, New species, Distribution, Host plants, Ecology, Biology.

Resúmen: Se describen tres nuevos géneros, Epactiohellica, en base a la nueva especie E. farinai, Alloeohellica basada en otra nueva especie, A. faundezi y Hellicoides, con la especie Hellica johni Froeschner. El género Hellica es redescrito con dos especies conocidas, $H$. nitida Haglund y $H$. johnpolhemi Froeschner y una nueva, $H$. kolla. Se describe por primera vez la ninfa del quinto estadio de Hellicoides johni y se redescribe la ninfa del quinto estadio de $H$. nitida. Algunos caracteres distribucionales (biogeografía, patrones de distribución), ecológicos (coloración, plantas hospedantes) y biológicos (ninfas, huevos) de estos géneros son comentados.

Palabras clave: Hemiptera, Acanthosomatidae, nuevos géneros, nuevas especies, distribución, plantas huésped, ecología, Biología.

\section{INTRODUCTION}

The genus Hellica, currently belonging to the family Acanthosomatidae, subfamily Blaudusinae, tribe Lanopini, was described by Stål in 1868, in his "Bidrag till Hemipterernas Systematik" (Contributions to Hemiptera Systematics) in an extensive work containing only keys of the Pentatomoidea and a key to higher levels in the Coreoidea, new and known until that moment. He included Hellica within the "Acanthosomatidum", Pentatomidae (page 533). At that time, Stål did not designate a type species because he originally did not include any species in the genus. It was a barren genus. Haglund (1868) added a single species, nitida, to the genus, so this became the type species by subsequent monotypy. This type-species, Hellica nítida Haglund (Fig. 1) was described based on, at least, one male specimen from "Amazonas" Brazil.
In 1884, Carlos Berg described Banasa pulchella based on six specimens, including both males and females from Uruguay. One of them is deposited in the Museo Argentino de Ciencias Naturales "Bernardino Rivadavia" (Bachmann, 1999) and three others are in the Museo de La Plata (Coscarón et al., 2015). The deposition of the remaining two syntypes is unknown. Berg does not make reference to the type-locality nor the number of nymphs that he briefly describes there, and they are probably also lost.

Under the name Banasa pulchella, Pennington (1920) cites the species for the first time for Buenos Aires province, Argentina. This species was also mentioned by Ruffinelli \& Pirán, 1959 from Uruguay.

Kumar (1974) briefly described the male of $H$. nitida (the female was not known at that time) in the context of a review of the acanthosomatid genera of the world. Rolston and Kumar (1974) 


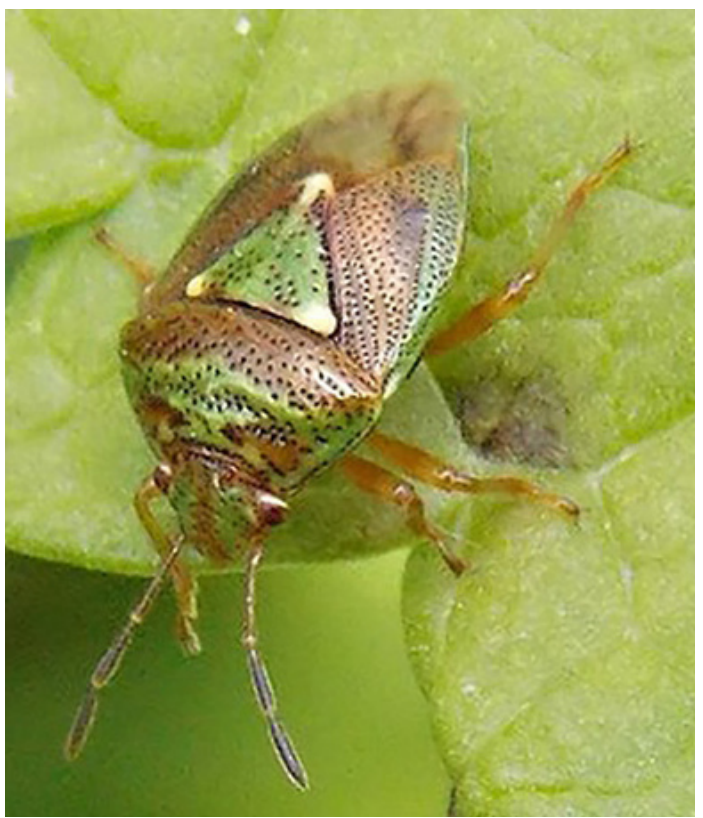

Fig. 1. Hellica nitida Haglund. The first author received this photograph for determination; the photographer's name was not provided. It comes from the "Reserva Natural Municipal del Pilar" (Buenos Aires). The authors thank the photographer who sent this beautiful photograph, regrettably for the moment remaining anonymous.

included this genus in their key to the genera of the Western Hemisphere. Banasa pulchella was finally synonymized with $H$. nitida by Thomas \& Yonke (1990) and confirmed by Froeschner (2000). Concerning the taxonomy of Hellica, the last and most extensive study was the work of Froeschner (2000) in which he diagnosed and discussed $H$. nitida and described two new species: H. johni and H. johnpolhemi. More recently, Carpintero \& De Biase, 2011 (list), Carpintero et al., 2014 and 2015 (lists), Coscarón et al., 2015 (type-species), Di Iorio \& Turienzo, 2015 (list), Dellapé, 2016 (list), Coscarón, 2017 (catalogue), mentioned this species.

In this work, the authors propose to describe new taxa, redescribe known taxa and comment on previously unknown biological and ecological aspects of this "genus complex" (Hellica Hellicoides - Epactiohellica - Alloeohellica). Not having yet a final phylogenetic analysis of the Lanopini (Carvajal et al., 2017), we will use this concept to refer to this group, which we consider to be a sister-group of genera, of the same lineage or clade, based on the following characters: small size, small and particular shape of ostiolar peri- treme, and as Kumar (1974) said: "Its distally broad and flattened anteclypeus is an uncommon feature in Acanthosomatidae". It is also to highlight its isolated geographical distribution, the different environment in which they are found, and the host plants that are quite different from the host plants of other South American acanthosomatid species. We will also discuss the differences that separate these new taxa from Hellica, and separate them from each other in the discussions of each of them.

\section{MATERIALS AND METHODS}

The photographs were taken with an Olympus DP 25 digital camera mounted on an Olympus SZF16 magnifying glass, using the Cell-Sense Standard program. The terminology concerning morphology and descriptive format follows Faúndez et al. (2014) for description of adults, and Martinez et al. (2003) for description of nymphs.

The measurements are given in millimeters $(\mathrm{mm})$, giving number of specimens measured (n), minimum measure, maximum measure and in between, in parentheses, the mean. The studied material is deposited in the entomological collection of Museo Argentino de Ciencias Naturales "Bernardino Rivadavia" (MACN) of Buenos Aires city and entomological collection of the $\mathrm{Mu}$ seo Municipal de Ciencias Naturales Lorenzo Scaglia (MMLS) of Mar del Plata (Buenos Aires province, Argentina).

\section{RESULTS}

\section{BLAUDUSINAE Kumar, 1974 \\ TRIBE LANOPINI Kumar, 1974}

\section{Epactiohellica gen. nov.}

(Figs. 2, 3)

Type species: Epactiohellica farinai sp. nov., by present designation.

Diagnosis. This genus is characterized by its shape, elongate and slightly flattened dorsoventrally, the densely punctured body, the small size, the short antennae with segments of subequal length, the flat and long paraclypei, nearly reaching the apex of the anteclypeus, the wide bucculae, the short legs with robust femora, and the absence of Pendergrast's organs in females.

Description. Oval-elongate, small species, slightly flattened dorso-ventrally, in lateral view, margin of hemelytra and pronotal carina form- 


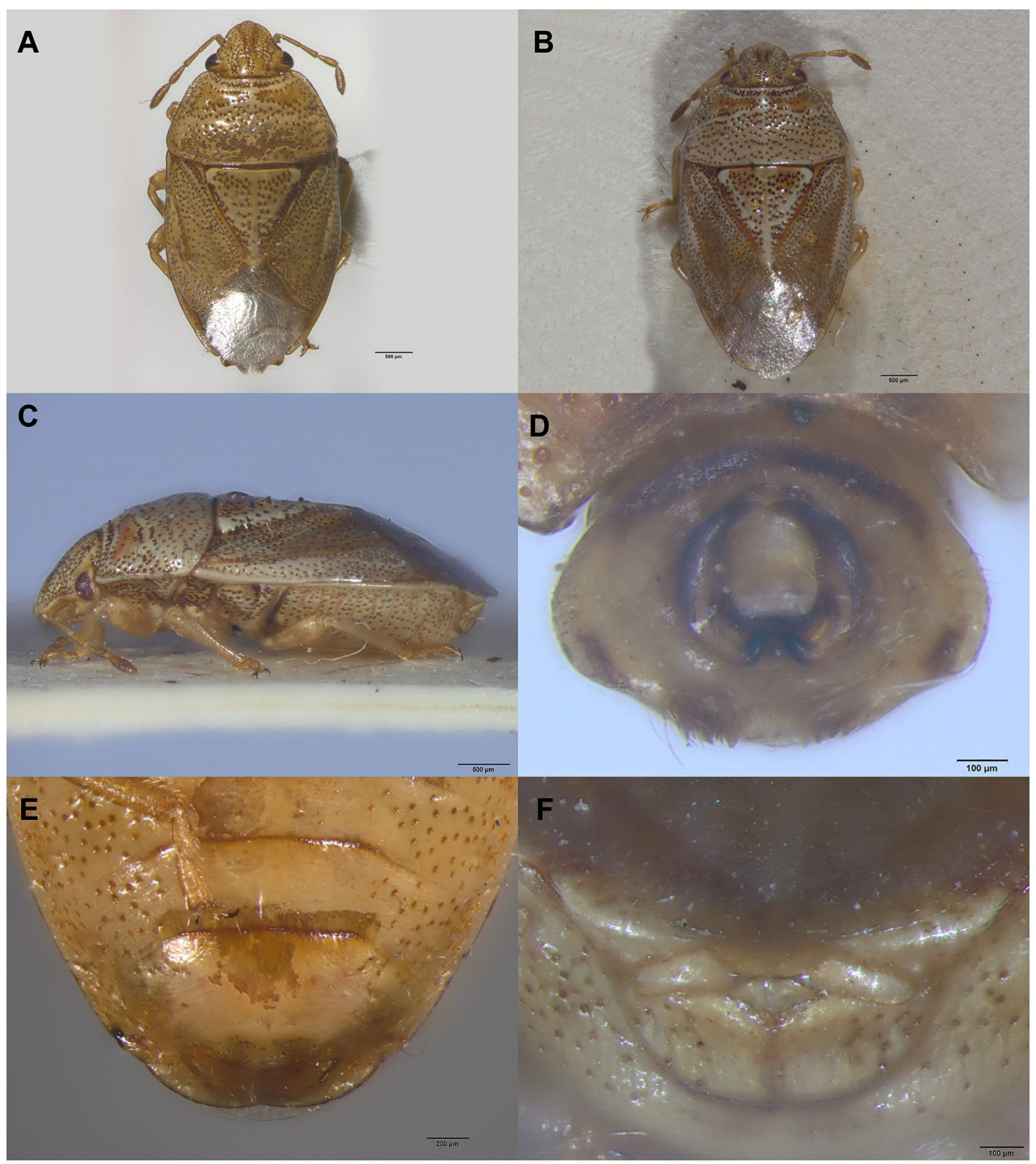

Fig. 2. Epactiohellica farinai sp. nov. A. Male, dorsal view. B. Female, dorsal view. C. Female, lateral view. D. Male, pygophore dorsal view. E. Female, abdomen ventral view. F. Female, genitalia caudal view.

ing a very small angle (compared to Hellica nitida) (Fig. 2C). Dorsal surface covered with small, deep punctures, densely dispersed throughout its entire dorsal surface.

Head (Fig. 5A). Anteclypeus densely punctured all along its length, extending slightly beyond anterior end of paraclypei; the latter flattened in their lateral margin; apically its mesial margin slightly overlapping anterior margin of an- teclypeus. Lateral margins of head slightly concave. Antennae short, all five segments of similar length; antennal segment I reaching near the middle of paraclypei; second segment reaching apex of clypeus. Bucculae wide with subparallel dorsoventral margins, covering nearly entire broadness of labial segment I, only ventral margin slightly visible, with a basal punctured line and other points beyond it. Labial segment 
I slightly surpassing posterior end of bucculae, labium extending to metacoxae. Head ventrally densely punctured.

Thorax. Pronotum subquadrangular; cicatrices immaculate; lateral margins of pronotum straight, strongly carinate, more broadly on its anterior half; humeral angles rounded, a little produced. Scutellum longer than wide at its base, with an ivory callus on each side of base. Hemelytra not covering connexiva on its apical half; basal margin of membrane arising near apex of abdomen. Sternal area without median carina. Each ostiolar peritreme short, twisted, protruding, apically with spiniform process; evaporatoria densely punctured similarly as remainder of thoracic venter. Legs short; femora robust; each tibia flattened ventrally on its apical half, with tuft of spiniform, dark bristles near middle, this tuft may have a stridulatory function as observed in all other species of this genus-complex, and in many other genera of this family.

Abdomen. Strongly, densely punctured except medially. Connexiva with very small, shallow punctures. Basi-abdominal spine present, short, apically rounded, reaching to middle of hind trochanters. Pendergrast's organs absent in females. In males, lateral margins of 7th sternites nearly straight; pygophore subrhomboid, posterior margin strongly convex, slightly prominent in mesial portion of posterior edge.

Etymology. prefix Epaktios - from the Greek, meaning "coastal, from the coast" (Brown, 1985), because the four collection sites of this species were on the marine coast, and -hellica from the closely related genus Hellica. The gender is feminine.

Discussion. Beyond its functional importance (Fischer, 2006; Tsai et al., 2015) the Pendergrast's organ is a character not yet used in the definition of Acanthosomatidae genera. Its form and relative location, and even its presence/absence are nonetheless constant and very characteristic of each genus. From this study, the authors present this character as useful and complementary to other characters for the discernment of the South American genera of this family.

Epactiohellica differs from the closely related genus Hellica by its smaller size, the density of the punctures on its body, the shorter antennal segments and legs, the wider bucculae, and by the absence of Pendergrast's organs in the female (Fig. $3)$. In addition to the above, it differs from Hellicoides by the flattened (not concave) paraclypei.

\section{E. farinai sp. nov. \\ (Figs. 2, 3)}

Studied material. HOLOTYPE, MACN-En. 34206. Male, ARGENTINA: Buenos Aires, San Clemente del Tuyú, 23-31/XII/1952, N. Kormilev (MACN). PARATYPES: 6 males and 5 females, same collection data as the holotype (MACN); 1 male, Mar Chiquita Reserve, III-2002, pitfall, Cicchino (MACN); 1 female, Pto. Achaval (Mar de Cobo), Pdo. de Mar Chiquita, 12-IV-1989, col. J. L. Farina (MMLS); URUGUAY: Maldonado: 1 female, Punta del Este (MACN).

Description. Male (Fig. 2A). Measurements: $(\mathrm{n}=5)$. Total length 4.07 (4.53) 4.76; width: 2.08 (2.35) 2.48; head length: 0.91 (0.98) 1.05; width: 1.11 (1.20) 1.24; interocular space: $0.75(0.81)$ 0.85 ; antennal segment lengths, I: $0.23(0.25)$ 0.28 ; II: 0.23 (0.28) 0.31 ; III: 0.24 (0.26) 0.29 ; IV: $0.27(0,31) 0.35$; V: $0.41(0.42) 0.46$; pronotum length: 0.99 (1.11) 1.20 ; width at base: 1.97 (2.28) 2.43; scutellum length: 1.18 (1.34) 1.43; width: 1.09 (1.28) 1.41.

General coloration yellowish-brown dorsally, with calli, base of scutellum, and endocorium pale reddish; lateral margins of scutellum whitish with dark brown punctures; venter yellowish-brown. Head. (Fig. 5A). Wider than long (0.2 times), entirely covered by dense, dark brown punctures, which are homogeneously distributed throughout except around eyes and in two short, smooth, longitudinal bands between ocelli. Antennal segment II very short, but longer than third, and subequal in length to fourth; fifth segment longer. Eyes small, prominent, rounded laterally, their mesial and basal margins straight, junctures between margins angulate; ocelli rounded, larger than surface punctures, not contiguous with pronotum. Posterior margin of bucculae at level with middle of eyes; apex of labium reaching mesosternum; labial segment II longest, third segment shorter than second but slightly longer than fourth segment; third and fourth segments smaller in diameter than observed in species of Hellica.

Thorax. Pronotum two times wider than long; dorsal surface covered by dense, strong, brown punctures; calli, anterior and posterior margins of pronotal collar smooth. Scutellum apically narrow, with uniform, disperse, brown punctures, except along sublateral margins and within a median line, which are smooth; a small, ivory callus in each humeral angle, associated with a fovea (on each side) with dark brown punctures. Hemelytra slightly convex; clavi and 


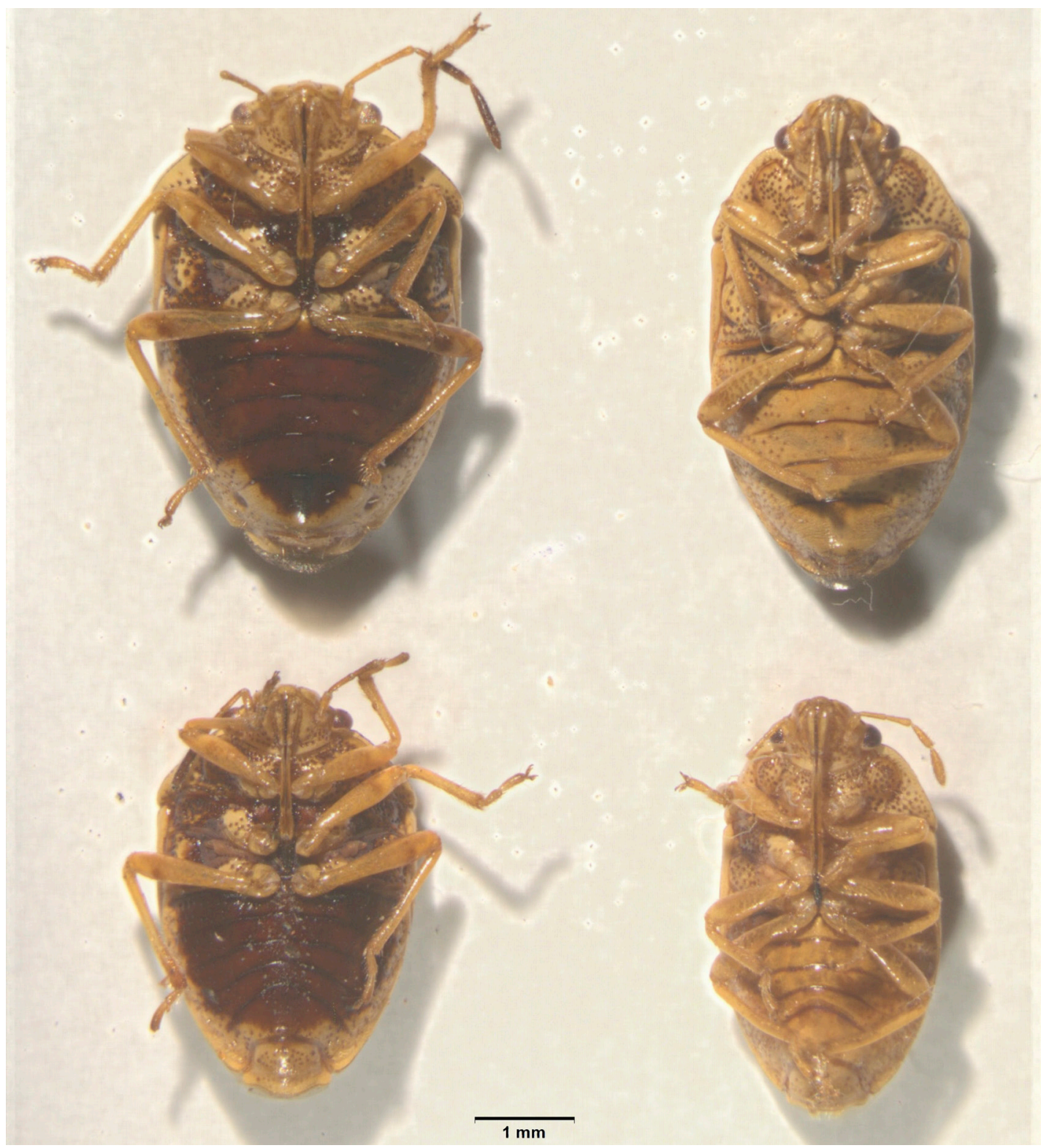

Fig. 3. Ventral view of Hellica nitida (left) and Epactiohellica farinai (right). The females are at the top and the males are at the bottom.

coria densely punctured; membrane hyaline, each with a median brown stripe, and a few weak longitudinal veins. Thoracic sterna covered with dense brown punctures, interspersed with a few smooth patches. Legs concolorous with body, tibiae and tarsi with broad, suberect, golden hairs on their inner margins, becoming more dense towards their apical halves; second tarsal segment longer than first.
Abdomen. Connexival segments concolorous with body, punctured. Genitalia: Pygophore (Fig. 2D) slightly punctured along lateral margins, ventral rim slightly concave medially, with two tufts of golden, erect hairs, which are visible in dorsal and ventral views; parameres narrow, elongate, with basal portions laterally black, extremely curved, touching apices of both parameres; apices of parameres sharpened, apically pointing forward. 
Female (Fig. 2B). Measurements: $(\mathrm{n}=5)$. Total length: 4.35 (4.77) 5.11; width: 2.23 (2.50) 2.68; head length: 0.95 (1.07) 1.11; width: 1.15 (1.24) 1.30 ; interocular space: $0.78(0.85) 0.90$; antennal segment lengths, I: 0.24 (0.26) 0.28 ; II: 0.28 (0.30) 0.34; III: $0.25(0.26) 0.27$; IV: $0.28(0.31)$ 0.33 ; V: 0.39 (0.42) 0.44 ; pronotum length: 1.02 (1.17) 1.27 ; width at base: 2.17 (2.46) 2.63; scutellum length: 1.34 (1.46) 1.57; width: 1.23 (1.41) 1.55 .

Similar to male in coloration; Pendergrast's organs absent (Fig. 2E). Genitalia: First gonocoxae elongate, wide, surface rugose, each gonocoxite markedly convex posteriorly; second gonocoxae small, with each gonocoxite nearly rectangular posteriorly; paratergites 8 narrow, rounded posteriorly; paratergites 9 acute posteriorly, straight anteriorly (Fig. 2F).

Etymology. The specific name is dedicated to our friend Juan L. Farina who has contributed greatly to the knowledge of the entomological fauna of the southeastern regions of the province of Buenos Aires.

Distribution. ARGENTINA: Buenos Aires, URUGUAY: Punta del Este (Fig. 7).

Host plant. Overlaying their geographic distributions and environments in which they have been found, the authors hypothesize that $E$. farinai occurs primarily on Bolboschoenus maritimus (L.) Palla subspecies paludosus (A. Nelson) T. Koyama (previously known as Scirpus robustus Pursh paludosus (A. Nelson) Fernald) (Cyperaceae); an association that had not been verified until now.

Discussion. See under genus.

\section{Alloeohellica new genus}

(Fig. 4)

Type species: Alloeohellica faundezi sp. nov., by present designation.

Diagnosis. This genus is characterized by the long hairs on the labium and legs, by the large eyes, and by the elongate hemelytra, which exceeds beyond the apex of the abdomen.

Description. Oval elongate, medium-sized species; in lateral view, pronotum (without lateral carina) and head forming medial angle with respect to dorsal profile (Fig. 4B). Dorsal surface covered with narrow, scattered punctures.

Head (Fig. 5B). Short, wide; lateral margins not flattened; head ventrally sparsely punctured. Anteclypeus with few punctures on basal third, extending well beyond apices of paraclypei, which are apically narrow and lateral margins curved, and mesial margins opening towards apices, causing anteclypeus to be twice as wide apically than basally. Antennae long, surpassing base of pronotum (when stretched posteriorly); segment I reaching, or sometimes slightly surpassing apex of head; segment II slightly longer than III; segments II and III longer than segments IV and V. Bucculae narrow, covering less than half the broadness of labial segment I, with a few basal punctures, appearing smooth. Labium short, only reaching base of mesosternum; covered by erect hairs which are longer than broadness of labial segments, aligned along its ventral margin (Fig. 4E); labial segments I and II narrow in diameter, segment III slightly enlarged in diameter, segment IV less enlarged.

Thorax. Lateral margins of pronotum straight, not carinate. Scutellum 0.2 times wider along base than medial length. Ostiolar peritremes small, twisted, protruding, each with apical spiniform process. Legs with sparse, long, erect hairs on ventral surfaces (Fig. 4D); femora broader than tibiae, but not particularly short or robust; tibiae not flattened ventrally on apical halves; tarsomere I much shorter than segment II, also with long hairs.

Abdomen. Basi-abdominal spine present, somewhat more elongate than in other genera of this complex, reaching bases of posterior coxae, apically rounded. Extreme margins of connexival segments smooth. In males, lateral margins of 7th sternites slightly curved; pygophore with setae along posterior margin, grouped in loose patches.

Etymology. prefix Alloios - from the Greek, meaning "of another kind, different" (Brown, 1985) and-hellica, from Hellica, the first described genus of this group. The gender is feminine. Discussion. Alloeohellica gen. nov. differs from the closely related genus Hellica by the shorter and wider head, the larger eyes, the longer antennae, the erect pilosity on the ventral surfaces of labium and legs, which is greater in length than the width of the segments (much more so than in the other species of this complex), and by the particular shape of pygophore and the apically spatulate parameres.

\section{Alloeohellica faundezi sp. nov.} (Fig. 4)

Studied material. HOLOTYPE, ARGENTINA: Buenos Aires, Male, Laguna de los Padres (Partido de General Pueyrredón), 7-IV-1990, col. J. L. Farina. (MMLS). 


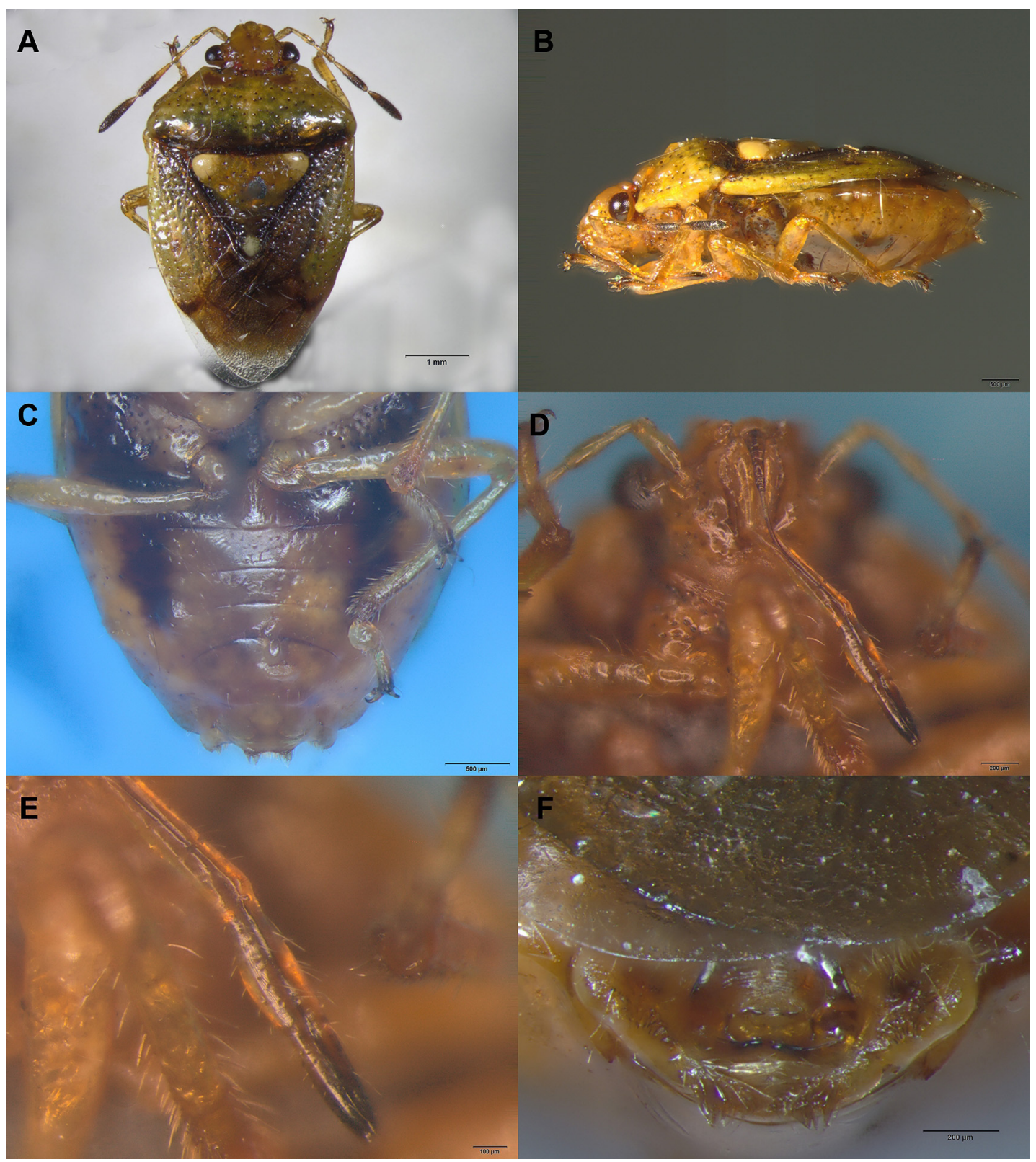

Fig. 4. A. faundezi sp. nov. A. Male, dorsal view. B. Lateral view. C. Abdomen ventral view. D. Head ventral view. E. Detail of labium. F. Pygophore dorso-caudal view.

Description. Male (Fig. 4A). Measurements: $(\mathrm{n}=1)$. Total length: 5.72 ; width: 3.28 ; head length: 1.00; width: 1.51; interocular space: 0.92; Antennal segment lengths, I: 0.39; II: 0.45; III: 0.42 ; IV: 0.71 ; V: 0.81 ; pronotum length: 1.31; width at base: 3.35 ; scutellum length: 1.64 ; width: 2.00 .

Medium-sized species, less than $6 \mathrm{~mm}$ long. Dorsally pale greenish with extreme base of pronotum, clavus, mesial margins and apices of endocoria, dark brown. Head pale greenish, unicolorous. Each callus with a small dark spot ahead of him. Scutellum pale greenish without black blotches at base. Ventrally, same coloration as dorsum, abdomen yellow, with a longitudinal sublateral dark area on each side, reaching to posterior margin of fifth sternite (Fig. 4C). 
Head. (Fig. 5B). Wider than long (0.5 times), entirely covered with sparse, dark-brown punctures. Eyes large, prominent, rounded laterally, their mesial and basal margins straight, juncture between these margins angulate; ocelli rounded, larger than surface punctures, nearly contiguous with pronotum. Posterior margins of bucculae ending near level with middle of eyes. Labium reaching base of mesosternum; labial segment I short, not surpassing posterior margins of bucculae, second segment longest, third segment shorter than second, but slightly longer than fourth.

Thorax. Pronotum subquadrangular, two and a half times wider than long, lateral margins rounded, without lateral carinae; dorsal surface covered by sparse, strong, brown punctures, anterior lobe more sparsely punctate. Scutellum apically narrow, with uniform, disperse, brown punctures, except along sublateral margins which are smooth, and two small, ivory calli one in each humeral angle. Hemelytra slightly convex, sublinear; clavi densely punctate; coria sparsely punctate; membranes long, extending far beyond apex of abdomen, hyaline with a few weak longitudinal veins. Thoracic sterna covered with dense brown punctures interspersed with some smooth patches. Legs concolorous with body, tibiae and tarsi with broad, suberect, golden hairs on their inner margins, becoming more dense towards their apical halves.

Abdomen. Very small, scattered punctures along lateral margins. Connexival segments in dorsal and ventral views, concolorous with body. Genitalia: Pygophore with basal angles protruding, with a large tufts of hairs on each basal angle, sparsely punctured; ventral rim straight medially; parameres narrow, quite curved, with basal portions apically rounded, flattened, spatula-shaped; apices of parameres sharpened, acute, curved inwards. (Fig. 4F).

Female: Unknown.

Etymology. The specific name is dedicated to Dr. Eduardo I. Faúndez in recognition of his contributions towards our studies of South American Acanthosomatidae.

Distribution. ARGENTINA: Buenos Aires (Fig. 7).

Host plant. Unknown.

Discussion. Unfortunately, the only known specimen is dotted with a substance that complicates seeing some details. On the other hand, those characters important for its separation from other related genera and species are visible.

\section{Hellicoides new genus}

(Fig. 6)

Type species: Hellica johni (Froeschner, 2000), by present designation.

Diagnosis. This genus is characterized by having the paraclypei marginally concave and subequal in length to anteclypeus, antennal segment II always longer than III and in females, and the Pendergrast's organ vestigial.

Description. Oval, medium-sized species with paraclypei depressed, curved anteriorly. Dorsal surface covered with strong, deep, dense punctures.

Head (Fig. 5D). Lateral margins of head flattened; head sparsely punctate ventrally. Anteclypeus extending apically almost at the same level as the paraclypei with many punctures only on the basal half; the latter depressed, concave, subapically flattened along their lateral margins; apically, their mesial margins slightly overlapping lateral margins of anteclypeus anteriorly; anteclypeus approximately of uniform width for its entire length. Antennae long, segment I not reaching apex of head, segment II always longer than III; segments II + III together longer than IV or V. Bucculae narrow, covering less than half the broadness of labial segment I, with some basal, shallow punctures, appearing smooth. Labium short, only reaching base of mesosternum; labial segments I and II narrow in diameter, segment III not particularly enlarged in diameter, segment IV less enlarged.

Thorax. Lateral margins of pronotum straight, without well-developed carinae. (Fig. 6C). Scutellum with ratio of medial length/basal width subequal. Ostiolar peritremes small, twisted, protruding, each with apical spiniform process. Legs with femora broader in diameter than tibiae, but not particularly short or robust; tibiae not flattened ventrally on their apical halves; tarsomere I much shorter than II.

Abdomen. Strongly but sparsely punctured, except in a medial, longitudinal band. Basiabdominal spine present, short, apically rounded, reaching to middle of hind trochanters. Extreme margins of connexival segments smooth. Pendergrast's organs present, but only slightly developed, restricted to anterior half of sternite VII (last pregenital segment), scarcely darker than rest of ventrite, glabrous, with punctures inside. In males, lateral margins of 7 th sternite slightly curved; pygophore subrhomboid.

Etymology. Suffix -oides from the Greek, meaning "like, resembling, having the form of" 


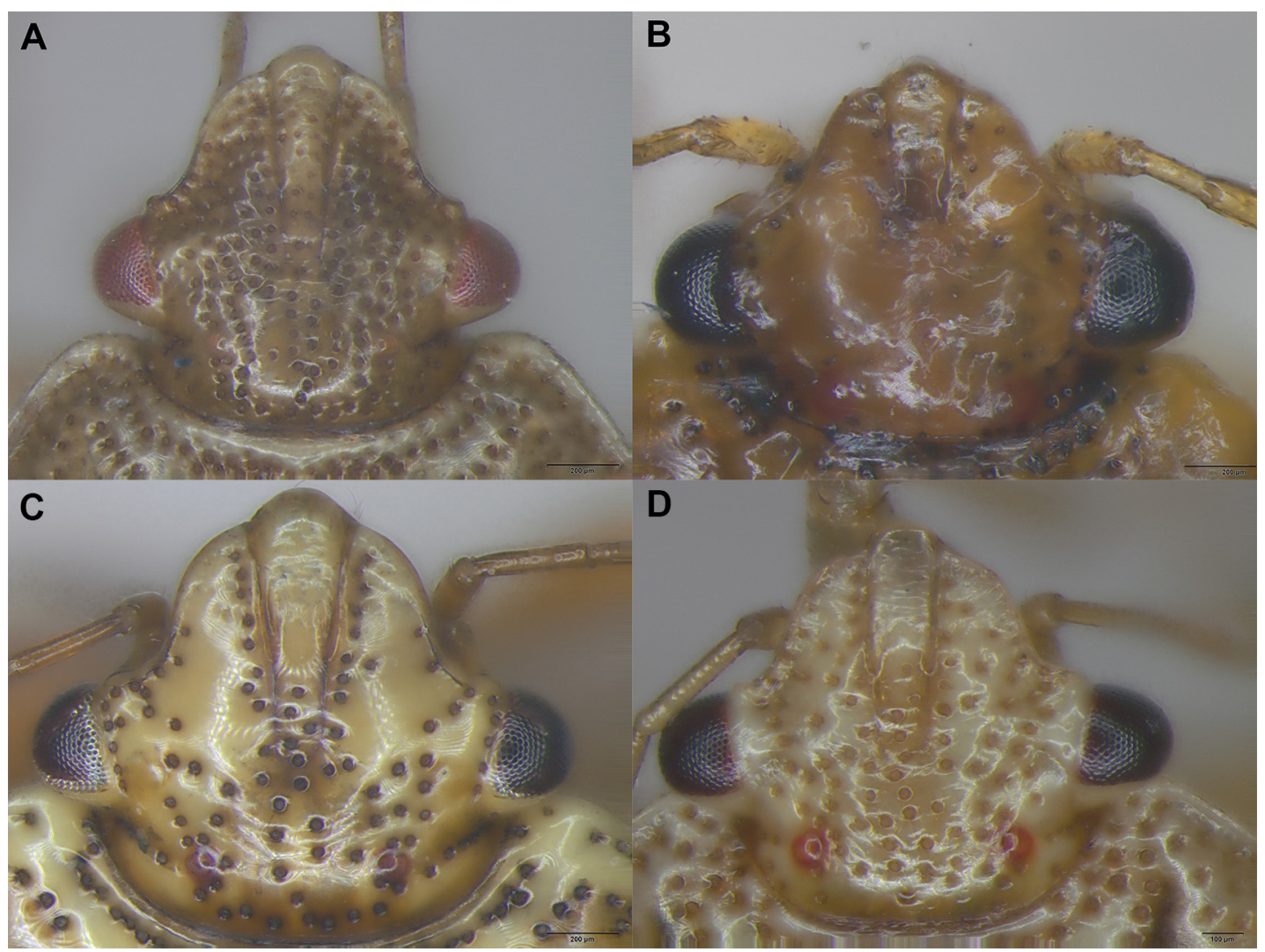

Fig. 5. Heads in dorsal view. A. E. farinai sp. nov. B. A. faundezi sp. nov. C. H. nitida Haglund. D. H. johni (Froeschner).

(Brown, 1985) after the prefix hellic- from the closely related genus Hellica. The gender is feminine.

Discussion. The more elongate habitus, the distinctive shape of the anteclypeus and the paraclypei (concave and of subequal length), characters already highlighted by Froeschner (2000), along with the relative lengths of antennal segments II and III (II longer than III), and the characteristics of Pendergrast's organs, lead us to propose that this species is not congeneric with Hellica.

\section{Hellicoides johni (Froeschner, 2000)} (Fig. 6)

Hellica johni Froeschner 2000: 166; Grazia \& Schwertner 2015: 402; Dellapé 2016: 84; Coscarón 2017: 11.

Studied material. ARGENTINA: Buenos Aires (city), 1 male, 7479 (MACN); 10 males, 6 females, 1 nymph (I), 2 nymphs (V), CABA, Res. Costanera Sur, 2-II-2019, De Biase - Carpintero, on Scirpus giganteus (MACN); Buenos Aires (province), 1 male, Isla Talavera (Partido de Campana), 30-X-2004, Carpintero (MACN); 1 male, 26949, San Isidro, Gemignani - Daguerre (MACN); 5 males, 42109, Tigre, II-1938, De Carlo - Viana (MACN); 1 male, same locality, M. J. Viana (MACN); 2 males, same locality, 25.51945, M. J. Viana (MACN).

Description. Male (Fig. 6A). Measurements $(\mathrm{n}=5)$. Total length: 4.86 (4.94) 5.01; width: 2.67 (2.78) 2.91; head length: 0.90 (0.98) 1.02; width: 1.26 (1.27) 1.29; interocular space: $0.80(0.81)$ 0.82 ; antennal segment lengths, I: $0.23(0.26)$ 0.29 ; II: 0.37 (0.42) 0.48 ; III: 0.32 (0.33) 0.35 ; IV: $0.45(0.50) 0.53$; V: 0.59 (0.62) 0.64; pronotum length: 1.14 (1.23) 1.40; width at base: 2.65 (2.76) 2.91; scutellum length: 1.44 (1.51) 1.59; width: 1.47 (1.55) 1.62 .

General coloration reddish-brown (in living specimens) or yellowish-brown (in dry specimens) dorsally, with basal lobe of pronotum darker; in some living or fresh specimens, extreme base of pronotum is reddish; with a characteristic whit- 
ish, transverse, well-delimited " $\mathrm{H}$ " on anterior lobe. Scutellum whitish with two light-brown blotches along base, and a light brown longitudinal medial band. A small, dark-brown longitudinal band in centre of each corium, which is continued as a long, sublateral stripe on each membrane. Ventral surfaces yellowish-brown, with a tapering, longitudinal, fuscous area of varying width on each side; some specimens may have abdominal venter dark brown, except for abruptly-delimited yellow lateral margins, as in the other members of the genus- complex.

Head. (Fig. 5D). Wider than long (0.3 times), entirely covered by dense dark-brown punctures, which are distributed uniformly throughout, except for smooth, impunctate bands on internal margins between eyes and ocelli. Eyes small, prominent, rounded laterally, their mesial and basal margins straight, the juncture angulate. Ocelli rounded, larger than surface punctures, not contiguous with pronotum. Posterior margins of bucculae ending at level near middle of eyes. Labial segment I slightly surpassing posterior margins of bucculae, second segment longest, third segment shorter than second, but slightly longer than fourth; third and fourth segments smaller in diameter than observed in species of Hellica.

Thorax. Pronotum subquadrangular, more than two times wider than long; humeral angles rounded; dorsal surface covered by dense, strong, brown punctures, except for characteristic H-shaped spot of anterior pronotal lobe, and two sublateral bands and extreme base near scutellum, smooth. Scutellum apically narrow, with a few disperse, brown punctures medially, and two small ivory calli, one on each humeral angle. Hemelytra slightly convex; clavi densely punctured; coria densely punctate; hemelytral membranes hyaline, each with a median brown stripe, and a few weak longitudinal veins. Thoracic sterna covered with dense, brown punctures interspersed with some smooth patches. Legs concolorous with body; tibiae and tarsi with broad, suberect, golden hairs on their inner margins, becoming much more dense towards their apical halves.

Abdomen. Connexival segments in dorsal and ventral views, concolorous with body. Genitalia: Pygophore punctured along lateral margins, setae along posterior margin grouped in loose patches; parameres broad, angular apically, with basal portions apically sharpened, acute, black; apices of parameres also sharpened, acute, pointing back and up (Fig. 6F).

Female (Fig. 6B). Measurements $(\mathrm{n}=5)$. Total length: 5.05 (5.44) 5.65; width: 2.76 (2.86) 3.05; head length: 0.95 (1.01) 1.06; width: 1.23 (1.28) 1.30 ; interocular space: $0.80(0.83) 0.85$; antennal segment lengths, I: 0.23 (0.26) 0.27 ; II: 0.37 (0.42) 0.46 ; III: 0.29 (0.31) 0.34 ; IV: $0.47(0.50)$ 0.52 ; V: 0.56 (0.59) 0.61; pronotum length: 1.08 (1.17) 1.28 ; width at base: 2.63 (2.76) 2.98 ; scutellum length: 1.48 (1.57) 1.63; width at base: 1.51 (1.54) 1.61.

Similar to male in coloration. Pendergrast's organs present, but small, not well-developed, slightly darker than rest of sternite (Fig. 6D). Genitalia: "Last pregenital segment with posterior margin broadly concave, virtually transverse in middle third. Lateral end of second plate not covered by third genital plate (Fig. 6E)." (Froeschner, 2000).

Distribution. ARGENTINA: Buenos Aires, Formosa. URUGUAY: Montevideo (Fig. 7).

Host plant. Scirpus giganteus (Cyperaceae).

Discussion. See under genus.

Nymphs. There is only one nymph I and two nymphs V (see studied material). We believe, however, that it is interesting to give these measurements and descriptions since, even though we do not have enough material to see the variability, this is the first study that is made of the nymphs of this species.

First instar. Measurements $(\mathrm{n}=1)$. Total length 1.26 ; width 0.95 ; length of head 0.54 , width 0.71 , interocular space 0.42 ; antennal segment lengths, missing; pronotal length 0.26 , width at base 0.84 .

Body oval.

Head: Dark brown, with large scattered punctures. Eyes of silver color. Antennae and labium, pale brown. Paraclypei subtriangular, shorter than anteclypeus. Labium reaching the medium coxas.

Thorax: Pronotum dark brown, with lateral margins paler and legs whitish. Large scattered punctures: two transversal rows of punctuations on the anterior margin and one on the posterior margin. Pleural area dark brown with scattered punctuations. Legs whitish.

Abdomen: Mostly contracted, dark brown. The visible segments (1-3) with scattered rows of large punctures.

Fifth instar. (Fig. 12D). Measurements $(\mathrm{n}=2)$. Total length 2.95 (3.05) 3.16; width 2.26 (2.32) 2.37 ; length of head $0.58(0.63) 0.68$, width 1.06 (1.08) 1.11, interocular space $0.89(0.95) 1.00$; antennal segment lengths, I: $0.20(0.23) 0.26$; II: 


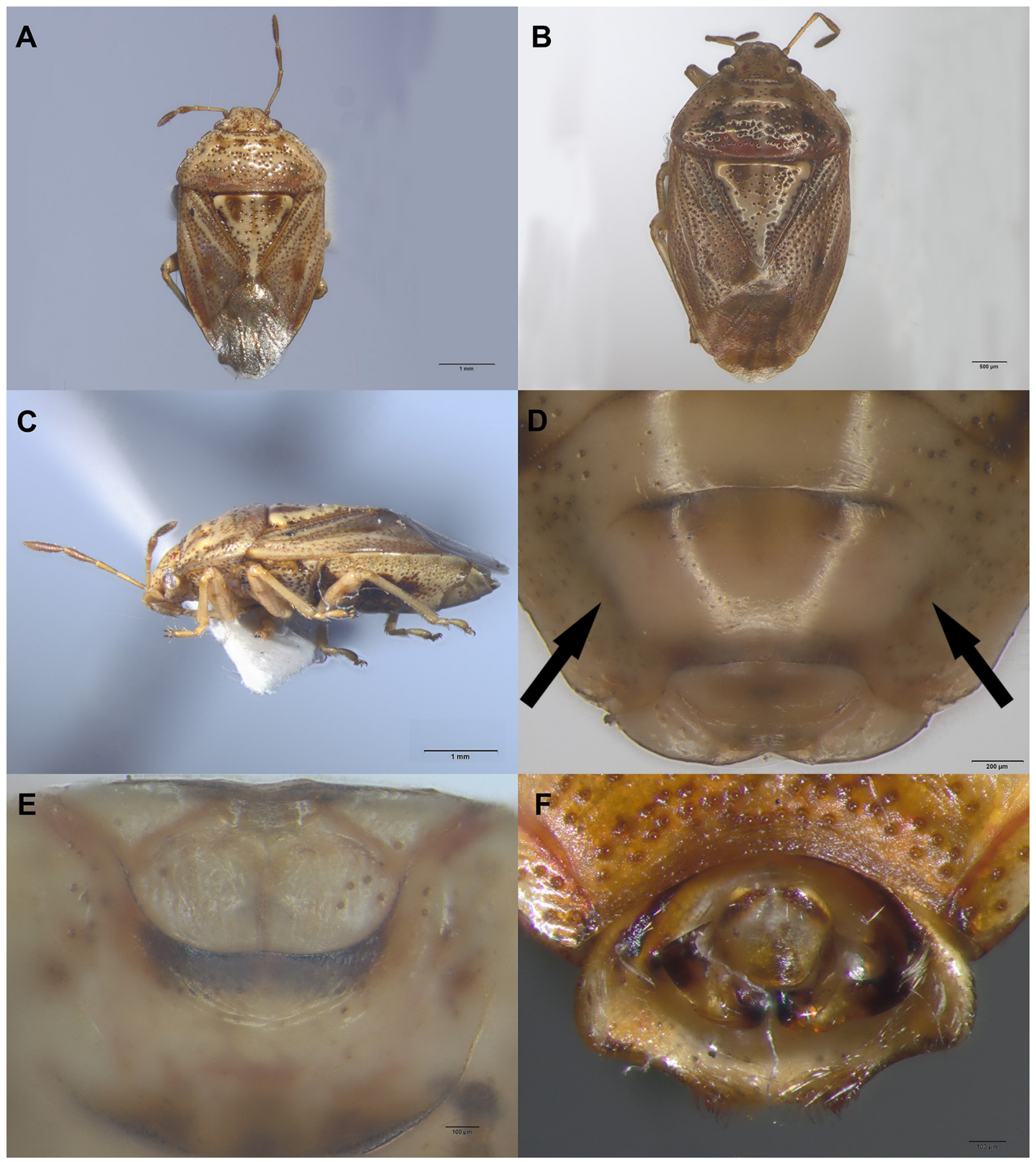

Fig. 6. H.johni (Froeschner). A. Male, dorsal view. B. Female, dorsal view. C. Male, lateral view. D. Male, pygophore dorsal view. E. Female, abdomen ventral view showing Pendergrast's Organs. F. Female, genitalia caudal view.

(0.45); III: 0.39 (0.40) 0.42 ; IV: 0.43 (0.45) 0.47 ; pronotal length 0.58 (0.69) 0.80 , width at base 2.00 (2.03) 2.06 .

Oval elongate.

Head: yellowish, with broad, longitudinal, light brown, medial line that narrows or disappears near middle of anteclypeus; subglabrous and homogenously punctured. Paraclypei as in adults, a slightly shorter than anteclypeus. Eyes small, prominent, rounded, greyish with a red line below each, posterolateral margins dark brown; primordia of ocelli red. Antennae pale brown; setae short, sparse on segments I and II, more abundant on segments III and IV; ratio of antennal segment lengths 1: 2.6: 2.2: 2.8. Labium pale brown with a red dot near its base, apex reaching hindcoxae.

Thorax: Pronotum light brown with two broad, 
dark-brown submedian longitudinal stripes, each with two medial light-brown circles; sparse and homogeneously punctured, subglabrous. Mesoand metatergum light brown, with dark brown stripes; punctured, subglabrous. Wing pads with similar stripes and punctures. Legs pale brown, a few short setae on femora and basal halves of tibiae, becoming more abundant, long on apical halves of tibiae and tarsi.

Abdomen: yellowish brown with intersegmental margins reddish, with short lines parallel to them of same color; densely punctured near lateral margins, along intersegmental sutures, and around scent glands, except area between scent glands; scent glands between segments III-IV, IV-V, V-VI and VI-VII: the first divided into two, more separated from remaining scent glands; second not divided, entire, somewhat wider than third, and last very small, non-functional. Abdomen with similar red lines as in dorsal view; punctures only along lateral margins; spiracles 2 to 8 sublateral; no visible setae. Ventrally pale brown, with two sublateral dark-brown stripes on pleural regions.

Discussion. Due to the distinct differences in shape, measurements, and coloration observed between the fifth instar nymphs of this species and Hellica nitida, we speculate that the immature forms present characters of high taxonomic value and as such, future projects on this family should include the study of immature forms.

\section{Hellica Stål, 1867}

Hellica Stål 1867: 533 (Type species: Hellica nitida Haglund 1868: 161, by subsequent monotypy); Stål 1872: 62; Lethierry \& Severin 1893: 258; Kirkaldy 1909: 179; Kumar 1974: 28; Rolston \& Kumar 1974: 272; Froeschner 1981: 8; Froeschner 2000: 165; Grazia \& Schwertner 2015: 402; Dellapé 2016: 84; Coscarón 2017: 11.

Description. Broadly oval, small to mediumsized species; in lateral view, margin of hemelytra and lateral margin of pronotum showing a wellmarked angle (Fig. 8C). Dorsal surface covered with strong, deep and sparse punctures.

Head (Fig. 5C). Lateral margins of head flattened; head sparsely punctured ventrally. Anteclypeus with some punctures on the basal quarter of its length, length extending well beyond apices of paraclypei (differing from illustrations in Froeschner, 2000); paraclypei with mesial margins divergent towards apices, allowing anteclypeus to be twice as wide apically than basally. Antennae long, segment I not reaching apex of the head; segment II always equal to or shorter than III (also differing from illustrations in Froeschner 2000); segments IV and V of equal length or longer than segments II and III taken together. Bucculae narrow, concealing less than half the broadness of labial segment I, with only a basal punctured line; labial segments I and II smaller in diameter; segment III particularly enlarged in diameter; segment IV less enlarged.

Thorax. Lateral margins of pronotum straight, not carinate. Scutellum wider along base than medial length. Ostiolar peritremes small, twisted, protruding, each with apical spiniform process (Fig. 8F, 9D, 11F). Legs with femora greater in diameter than tibiae, but not particularly short or robust; tibiae not flattened ventrally on their apical halves; tarsomere I much shorter than II (differing from illustrations in Froeschner, 2000).

Abdomen. Strongly and sparsely punctured except for a medial longitudinal band; basi-abdominal spine present, short, apically rounded, reaching hind coxae. Pendergrast's organs large, well-developed, dark, with short hairs, restricted to anterior half of sternite VII (last pregenital segment) (Fig. 8D). In males, lateral margins of 7th sternite slightly curved; pygophore subrhomboid.

Discussion. According to Froeschner (2000): "Among those (previously known) genera of the tribe Lanopini Kumar with juga not surpassing the tylus and humeri not projecting beyond the outline of the costa, Hellica is recognizable by the very short peritreme that is virtually no longer than wide". In addition to this definition, the genus Hellica differs from the rest of the Lanopini, by its geographical distribution. The discovery of new taxa with virtually the same morphological characters, and with similar distributions leads us to believe that a natural group of species has evolved in this region. This group of species, representing several different genera, is considered here to be a "genus-complex." To date, there has been no thorough phylogenetic analysis of the tribe, but it appears that this complex of genera has diversified at these latitudes, including particular morphological adaptations, which has led us to group them into at least four different, but closely related genera.

\section{Hellica nitida Haglund, 1868}

(Figs. 1, 3, 8)

Hellica nitida Haglund 1868: 161; Stål 1872: 62; Lethierry \& Severin 1893: 258; Kirkaldy 1909: 179; Ku- 


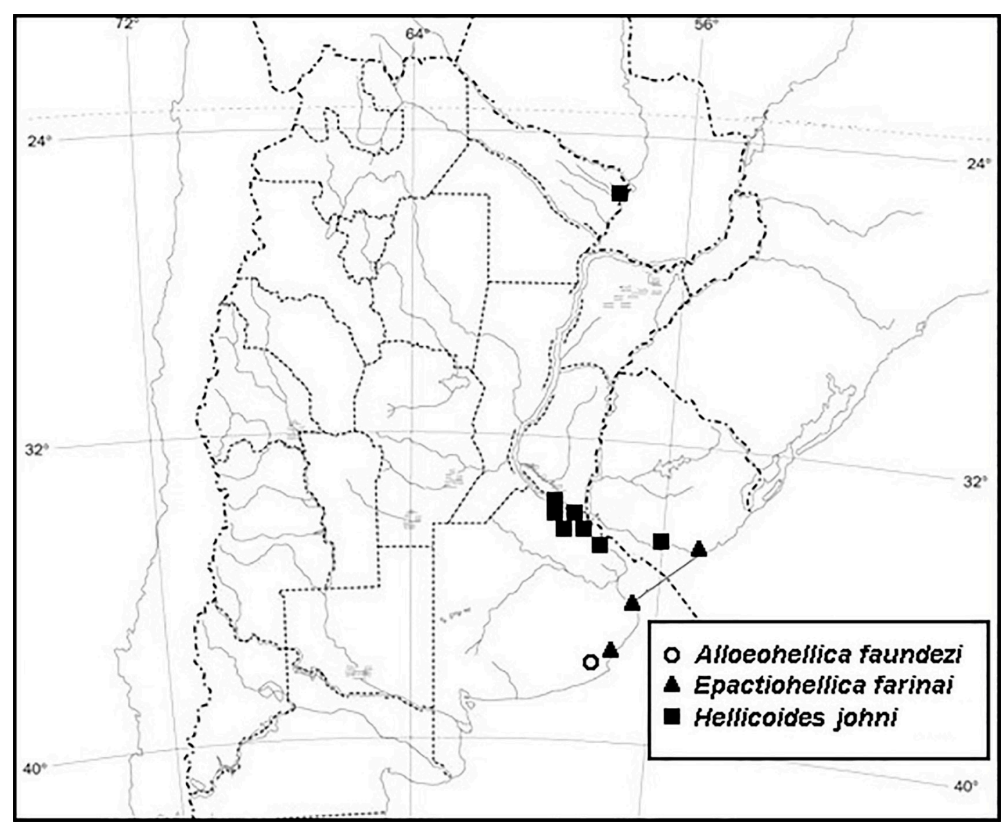

Fig. 7. Map of the distribution of genera Epactiohellica, Alloeohellica and Hellicoides.

mar 1974: 28; Thomas \& Yonke 1990: 657; Froeschner 1999: 169; Bachmann 1999: 210; Coscarón \& Grazia 2000: 25; Fisher 2006: 1045; Mendonça et al. 2009: 123; Grazia \& Schwertner 2011: 713; Carpintero \& De Biase 2011: 37; 2012 Weiler et al.: 188; Carpintero et. al. 2014: 77; Carpintero et al. 2015: 277; Grazia \& Schwertner 2015: 402; Di Iorio \& Turienzo 2015: 35; Coscarón et al. 2015: 89; Dellapé et al. 2015: 9; Dellapé 2016: 85; Melo et al. 2017: 496; Coscarón 2017: 11.

Banasa pulchella Berg 1884: 101; Lethierry \& Severin 1893: 168; Pennington 1920: 9; Bosq 1937: 122; Pirán 1948: 10; Ruffinelli \& Pirán 1959: 45; Quintanilla et al. 1976: 124; Viana \& Williner 1978: 71. Banasa (Atomosira) pulchella Kirkaldy 1909: 123.

Nezara (Atomosira) pulchella Pennington 1919: 530.

Bonasa [sic] pulchella Viana \& Williner 1972: 26.

Atomosira pulchella Grazia-Vieira \& Casini 1973: 58.

Studied material. TYPUS. Banasa pulchella Berg, URUGUAY: B(anda) O(riental), 1 male (MACN). ARGENTINA: Buenos Aires (city), 4 males, 3 females y 5 nymphs (V), 273 (MACN); 1 F, 15-I-1912, J. B. (MACN); 1 male, RECS (Reserva Costanera Sur), Vivero, 29-II2008, Carpintero (MACN); 3 males, 2 females, idem, Canal Viamonte, 27-II-2008, Carpintero (MACN); 1 female, idem, al costado Vivero, 14III-2010, Damer (MACN); 1 female, idem, canal cerca Vivero, 14-XI-2008, Carpintero (MACN); Buenos Aires (province), 1 female, Delta, 22-III1947, 3899, Leg. Bachmann (MACN); 1 male, idem, 3-XII-1945, 1212, Leg. Bachmann (MACN);
2 males, 2 females, idem, Paraná Guazú, II-1919 (MACN); 4 males, 1 female, 1 nymph, Res. Laguna de los Padres, 14-I-2019, on Cyperus eragrostis eragrostis (Cyperaceae), Carpintero (MACN); I. M. García, 15-II-1933, Daguerre - P. Moreau (MACN); 3 females, I. Talavera (Campana), 30X-2004, Carpintero (MACN); 4 males, 4 females, idem, XII-2004, Carpintero (MACN); 1 male, Res. Paititi (Gral. Pueyrredon), 29-X-2003, Cicchino (MACN); 1 male, San Isidro, 26949, Gemignani - Daguerre (MACN); 1 male, 1 female, Tigre, Daguerre J. (MACN); 1 female, idem, II-1938, De Carlo - Viana (MACN); 1 male, idem, 36806 (MACN); 2 males, 1 female, 1 male, Veronica (Punta Indio), IX- 2001, Carpintero (MACN); Chaco, 1 male, Fontana, 2-XI-1935, Daguerre (MACN); 1 male, II-1936, Viana (MACN); Corrientes, 2 males, 2 females, Nueva Valencia, X-1947, Viana (MACN); Entre Ríos, 3 females, Brazo Largo, La Selva, 15-II-1948 (MACN); 1 male, 1 female, Colón, 27218, Daguerre (MACN); 1 male, 1 female, Gualeguaychú excursión, 19IV-1924, 12833, Prof. M. D. Jurado (MACN); 6 males, 6 females, Paranacito, 29976, X-1931, Daguerre (MACN); Misiones, 1 male, Sta. María (Dto. Concepción), IV/V-1960, Viana (MACN); Santa Fe, 1 male, C. I., 17-XI-1927, Reboredo (MACN); 1 male, Piquete, 11-XII-1928, Bridaroli S. J. (MACN); Santiago del Estero, 1 male, S. D. E. City, +1 male of Microporus nigropunctatus (Berg) (Cydnidae) (MACN). BRAZIL: Paraná, 
2 males, Bituruna, Staviaski col. (MACN); Rio de Janeiro, 3 males, 2 females, Petrópolis, I e II-1958, D'Albuquerque (MACN). URUGUAY: Canelones, 1 male, Bañados de Carrasco, 25-XII1960, Monné (MACN); Cerro Largo, 1 male, Sta. Clara de Olimar, 12-V-1960, Zalessi (MACN); Colonia, 1 male, San Juan, II-1884, Speg(azzini) (MACN); 1 male, II-1989, Carpintero D. J. (MACN); Maldonado, 2 males, 2 females, Punta del Este, I-1963 (MACN); Rivera, 1 female, Arroyo de las Ánimas, I-1971, L. E. F. A. (MACN).

We have also examined an image of the lectotype (designated by Kumar, 1974) conserved in the Swedish Museum of Natural History (see: http:// www2.nrm.se/en/het_nrm/n/hellica_nitida.html)

Description. Male (Fig. 8A). Measurements $(\mathrm{n}=5)$. Total length: 4.71 (4.87) 5.11; width: 2.83 (2.94) 3.05; head length: 1.02 (1.12) 1.17; width: 1.40 (1.44) 1.51; interocular space: 0.93 (1.00) 1.05; antennal segment lengths, I: $0.28(0.29)$ 0.31 ; II: 0.30 (0.36) 0.41 ; III: 0.35 (0.39) 0.44 ; IV: $0.64(0.66) 0.68$; V: 0.71 (0.74) 0.77 ; pronotum length: 1.19 (1.31) 1.50; width at base: 2,85 $(2,96) 3,06$; scutellum length: 1.35 (1.50) 1.94; width: 1.67 (1.83) 2.26.

General coloration green dorsally, with calli, base of scutellum and endocoria light brown (in living specimens), basal angles and apex of scutellum whitish, with dark brown punctures; ventral surfaces green with legs light brown.

Head. (Fig. 5C). Wider than long (0.3 times), covered by strong, disperse dark-brown punctures, with two oblique rows of punctures on frons, additional rows along margins of paraclypei, another around eyes and another at base of head; a few scattered punctures on base of anteclypeus. Labium elongate, reaching metacoxae.

Thorax. Pronotum 2.5 times wider than long, laterally without carinae; dorsal surface covered by sparse, strong, brown punctures, posterior lobe homogenously punctured, anterior lobe only with punctures along its margins and around calli. Scutellum relatively broad apically, with a tight row of punctures along its margins, some scattered punctures in the centre; hemelytral membranes hyaline.

Abdomen. Connexival segments in dorsal view concolorous with body, mesially with a row of punctures. Genitalia: Pygophore with sparse punctures; parameres broad and elongate, with entire basal portion black, extremely rounded; apical portion of parameres angulate, pointed (Fig. 8E).
Female (Fig. 8B): Measurements: $(\mathrm{n}=5)$ Total length: 5.01 (5.14) 5.19; width: 3.11 (3.18) 3.31; head length: 1.08 (1.15) 1.25; width: 1.47 (1.50) 1.56; interocular space: 0.95 (1.02) 1.10; antennal segment lengths, I: 0.27 (0.31) 0.34; II: 0.38 (0.39) 0.40; III: 0.35 (0.40) 0.44; IV: $0.64(0.67)$ 0.73 ; V: 0.72 (0.72) 0.73 ; pronotum length: 1.24 (1.27) 1.29; width at base: 3.08 (3.19) 3.34; scutellum length: 1.45 (1.53) 1.61; width: 1.80 (1.87) 1.96.

Similar to male in coloration; Pendergrast's organs present on seventh sternite and well-developed.

Distribution. ARGENTINA: Buenos Aires (Pennington, 1920); Santa Fe (Bosq, 1937); Córdoba, Misiones, Tucumán (Pirán, 1948); Corrientes (Quintanilla et al., 1976); Formosa (Froeschner, 1999); Martín García Island (Carpintero \& De Biase, 2011). BRAZIL: Amazonas (?), Santa Catarina (Haglund, 1868); Rio Grande do Sul, Paraná (Mendonça et al., 2009). URUGUAY: Colonia (Berg, 1884).

New records. ARGENTINA: Chaco, Entre Ríos, Santiago del Estero (Fig. 10). BRAZIL: Rio de Janeiro. URUGUAY: Canelones, Cerro Largo, Maldonado, Rivera.

Host plant. Cyperus eragrostis eragrostis (Cyperaceae). We question the validity of the host plant records reported in the literature: Lagenaria siceraria (Molina) Standl. (Cucurbitaceae) (Bosq, 1937 as Banasa pulchella Berg). Solanum sp. (Solanaceae) (Di Iorio \& Turienzo, 2015).

Discussion. This species differs from $H$. johnpolhemi by its smaller size, by the coloration of the scutellum, and by the fact that the two species seem to prefer different habitats. That is, $H$. johnpolhemi has always been found above 1500 $\mathrm{m}$ asl, while $H$. nitida appears to be only found at lower elevations in the plain. From H. kolla sp. nov., it differs by its general coloration, by having broader parameres, and it is also usually found at higher altitudes, similar to $H$. johnpolhemi.

Nymphs. Fifth instar. (Fig. 12A, B) $(\mathrm{n}=5)$ Total length 3.16 (3.47) 3.79; width 2.84 (2.94) 3.04 ; length of head 0.74 (0.78) 0.84 , width 1.32 (1.39) 1.42, interocular space 1.00 (1.02) 1.06; antennal segment lengths, I: $0.24(0.27) 0.32$; II: 0.47 (0.51) 0.55 ; III: 0.50 (0.54) 0.58; IV: 0.58 (0.61) 0.64; pronotal length 0.89 (0.92) 0.95 , width 2.47 (2.59) 2.71 .

Description: Rounded oval.

Head. Light brown; subglabrous, homogenously punctured; anteclypeus red; paraclypei as in 


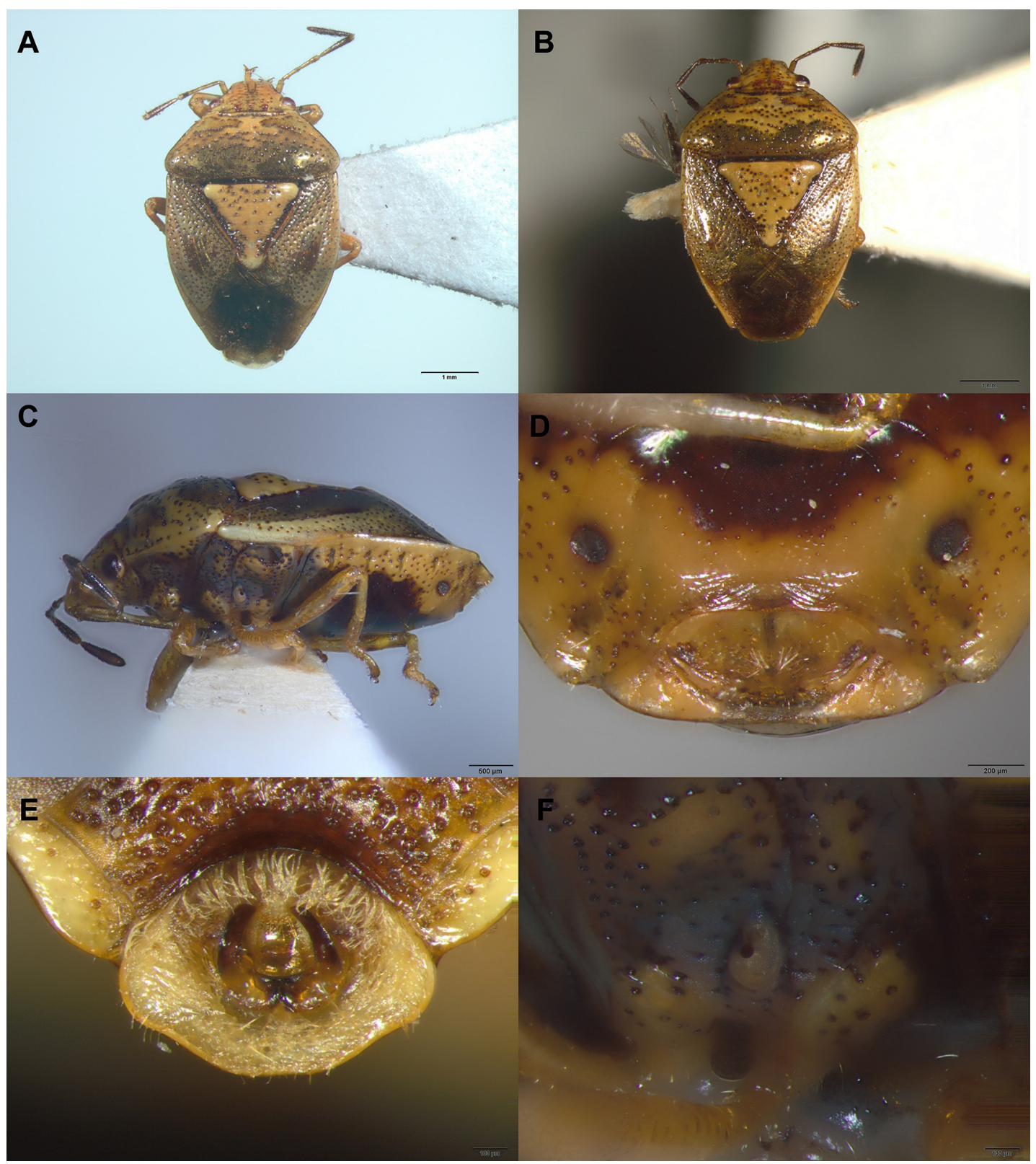

Fig. 8. Hellica nitida Haglund. A. Male, dorsal view. B. Female, dorsal view. C. Female, lateral view. D. Female, genitalia ventral view. E. Male, pygophore dorsal view. F. Metapleura.

adults, markedly shorter than anteclypeus. Eyes small prominent, rounded, greyish with anterior half of each red; primordia of ocelli red. Labium pale brown, reaching metasternum. Antennae pale brown, fourth segment darker; erect setae sparse on segments I to III, more abundant and mixed with very short, dense hairs on segment IV; ratio of antennal segment lengths 1: 1.8: 1.7: 2.1. Thorax. Pronotum yellowish-brown with two pale spots at the level of calli, each surrounded by reddish-brown semicircle; punctured as in adults, subglabrous. Meso- and metatergites subglabrous, with two smooth, pale sublateral bands and a medial, brown band which is darker laterally than medially, with scattered punctures. Wing pads yellowish-brown, darker along mesial margins, with scattered punctures. Legs pale brown, a few long setae on ventral surfaces 
of femora and on basal halves of tibiae, becoming more abundant on apical halves of tibiae and tarsi.

Abdomen. greenish (yellowish-brown in dried specimens) with lateral halves greenish, area surrounding scent glands yellowish-brown, scent glands, themselves, reddish brown; ventrally densely punctured towards the lateral margins, area surrounding scent glands smooth (Fig. $12 \mathrm{C}$ ), each scent glands surrounded by a row of punctures, with more punctures between them; those between segments III-IV, IV-V, V-VI and VI-VII: the first divided into two parts and more separated from the following; second not divided, entire, somewhat wider than third, and last very small, non-functional. Ventrally greenish brown. Abdominal venter only punctured along lateral margins; spiracles 2 to 8 sublateral; no visible setae.

\section{Hellica johnpolhemi Froeschner, 2000} (Fig. 9)

Hellica johnpolhemi Froeschner 2000: 168; Grazia \& Schwertner 2015: 402; Dellapé 2016: 84; Coscarón 2017: 11 .

Studied material. ARGENTINA: Jujuy, 1 female, Palpalá, II-1981, Carpintero (MACN); Salta, 2 females, 20-I-1897, 5653, S. Venturi (MACN); Tucumán, 1 female, Trancas, J. M. Arnau, II-1951, col. A. C. Pirán (as Banasa alboapicata Stål) (MACN); 1 female, Tucumán (MACN); 1 female, idem, 5656 (MACN).

Description. Female (Fig. 9A). Measurements $(\mathrm{n}=5)$. Total length: 6.00 (6.63) 7.20; width: 3.50 (3.86) 4.12; head length: 1.24 (1.35) 1.40; width: 1.67 (1.81) 1.87; interocular space: 1.08 (1.15) 1.21; antennal segments length, I: $0.31(0.36)$ 0.43 ; II: 0.50 (0.54) 0.57; III: 0.44 (0.47) 0.52 ; IV: 0.73 (0.77) 0.84 ; V: 0.87 (0.90) 0.93; pronotum length: 1.36 (1.51) 1.63; width at base: 3.45 (3.80) 3.97; scutellum length: 1.90 (2.12) 2.30; width: 2.01 (2.30) 2.47 .

Larger species, between 6 and $7.2 \mathrm{~mm}$ long. Dorsally pale brown with a narrow yellowish band on each exocorium. Head yellowish with a brown central stripe and a fuscous band in centre near basal margin. Scutellum yellowish and as stated by Froeschner (2000): "this species can be readily recognized by the presence of two (usually joined) black blotches at base of scutellum". Pronotum yellowish, basal lobe, excepting lateral margins, darker. Calli pale brown with a dark spot on each of them.
Head. Thirty percent wider than long, entirely covered with dark-brown punctures, which are uniformly sparsely distributed throughout except around eyes and two short, smooth, longitudinal stripes between ocelli.

Thorax. Pronotum more than two times wider than long, laterally without carinae (Fig. 9B); dorsal surface covered by strong, brown punctures; calli and anterior and posterior margins of pronotal collar, smooth. Scutellum wider than long, apically narrow, with uniform, disperse, brown punctures, except on basal half of sublateral margins. Hemelytra slightly convex; coria sparsely punctured. Thoracic sterna covered with dense, brown punctures interspersed with some smooth patches. Legs pale yellowish, second tarsal segment longer than first.

Abdomen. Connexival segments in dorsal and ventral views pale yellowish. Genitalia: According to Froeschner (2000): "the posterolateral margin of the third genital plate is convexly rounded, covering the lateral end of the second genital plate and slightly overlapping the posterior lateral angle of the basal genital plate" (Fig. 9C).

Male: Descriptive characters apply to both sexes (according to Froeschner, 2000). Genitalia: "the apical margin of the genital capsule is broadly and shallowly bilobed in the middle third; the posterolateral margin of the third genital plate is convexly rounded, covering the lateral end of the second genital plate and slightly overlapping the posterior lateral angle of the basal genital plate" (Froeschner, 2000).

Distribution. BOLIVIA: Quime (3048 msnm); ARGENTINA: Formosa (Froeschner, 2000) (see under Discussion); Tucumán, Jujuy (Dellapé, 2016).

New record. ARGENTINA: Salta (Fig. 10).

Host plant. Unknown.

Discussion. In the six specimens we have examined, the scutellum has a long, basal, black blotch. This character, its large size, and the characters of the genitalia, together with the fact that this species is found only at altitudes greater than 1500 $\mathrm{m}$ asl, differentiates this species from the other species of the genus. We have noted the presence of two blotches in all other species of the genus. Froeschner (2000) stated:"Because there were no males and females bearing the same locality data, there is a possibility they are improperly associated here..." Based on this, and considering that the Formosa specimen is geographically distant from the rest of the known material of this species (see Dellapé, 2016 and the current work), we consider that this specimen, which we 


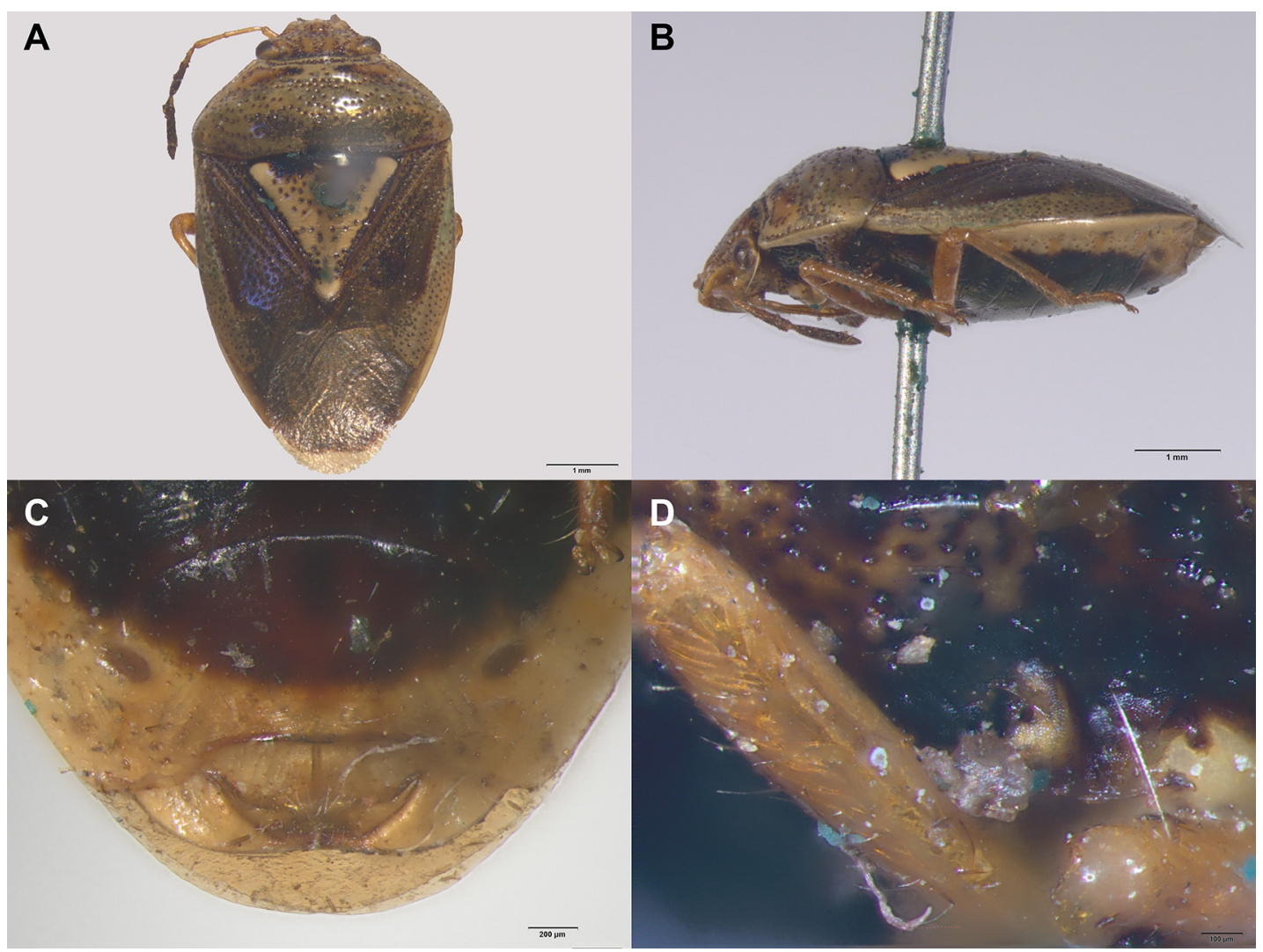

Fig. 9. Hellica johnpolhemi Froeschner. A. Female, dorsal view. B. Female, lateral view. C. Female, genitalia ventral view. D. Metapleura.

have not examined, probably belong to $H$. nitida. Froeschner's reference (2000: 169) to "Brazil: Tafe del Valle, Quebradada la Angostura" refers to Tafí del Valle, Quebrada la Angostura, Tucumán, Argentina (see also Dellapé, 2016).

\section{Hellica kolla sp. nov.} (Fig. 11)

Studied material. HOLOTYPE, MACN-En. 34205. Male, ARGENTINA: Salta, $10 \mathrm{~km}$ NO Comunidad Kolla de Los Naranjos (Dto. Orán), 1000m, VI-2007, 2305'55.26”'S 64²43'38.37'W, Carpintero coll. (MACN); PARATYPES: 1 male, 1 female, with same label data as the holotype (MACN).

Description. Male (Fig. 11A). Measurements $(\mathrm{n}=2)$. Total length: 5.20 (5.36) 5.52; width: 3.27 (3.31) 3.36; head length: 1.18; width: 1.56 (1.57) 1.58; interocular space1.04: (1.05) 1.06; antennal segment lengths, I: 0.39; II: 0.45 (0.45) 0.46; III: 0.46 (0.46) 0.47 ; IV: 0.74 ; V: 0.82 ; pronotum length: 1.26 (1.30) 1.35; width at base: 3.25 (3.29)
3.34; scutellum length: 1.56 (1.62) 1.68; width: 1.94 (1.96) 1.99.

Medium-sized species, less than $6 \mathrm{~mm}$ in length. Dorsally orange-brown with basal lobe of pronotum, clavi and mesial margins of endocoria, greenish; head orange yellowish, unicolorous; Calli pale brown with a dark spot on each of them. Scutellum orange yellowish with two black blotches at base. Ventrally, similar coloration as in $H$. nitida.

Head. Wider than long (0.3 times), entirely covered by sparse, dark-brown punctures, which are more abundant between eyes. Antennal segment I nearly reaching apices of paraclypei, second segment slightly shorter than or subequal to third segment, and second and third segments taken together much shorter than fourth and fifth segments. Eyes small, slightly prominent, rounded laterally, their mesial and basal margins straight, their juncture angulate; ocelli rounded, larger than surface punctures, nearly contiguous with pronotum. Posterior margins of bucculae ending at level near centre of eyes. Labium 


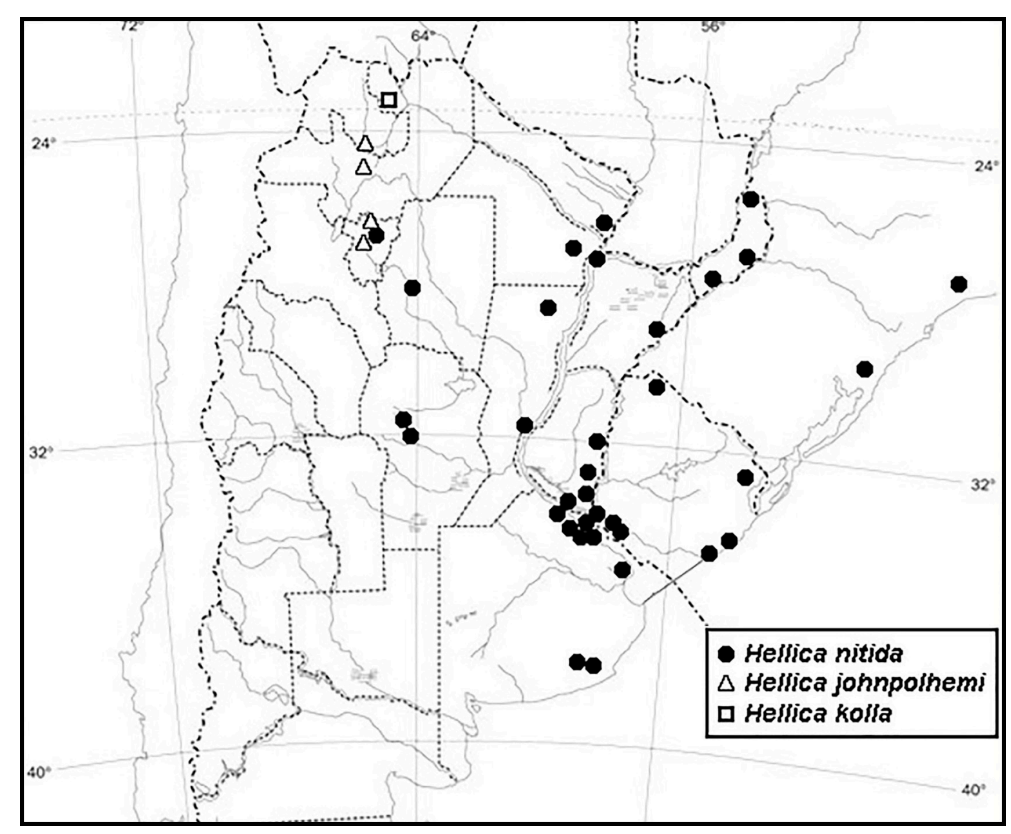

Fig. 10. Map of the distribution of genus Hellica species.

reaching middle of mesosternum; labial segment I short, slightly surpassing posterior margins of bucculae, second segment longest, third segment shorter than second but slightly longer than fourth; third and fourth segments broadened.

Thorax. Pronotum subquadrangular, two and a half times wider than long, laterally without carinae (Fig. 11B), humeral angles rounded; dorsal surface covered by sparse, strong, brown punctures; anterior and posterior margins of calli, and pronotal collar, smooth. Scutellum $20 \%$ wider than long, apically narrow, with uniform, disperse, brown punctures, except smooth sublateral margins and two small, ivory calli, one in each humeral angle. Hemelytra quite convex; clavi and coria densely punctured; membranes hyaline with a few weak, longitudinal veins. Thoracic sterna covered with dense brown punctures interspersed with some smooth patches. Legs concolorous with body, tibiae and tarsi with broad, suberect, golden hairs on their inner margins becoming more dense on their apical halves; second tarsal segment longer than first.

Abdomen. Connexival segments in dorsal and ventral views concolorous with body. Genitalia: Pygophore hairy along its margins, centrally punctured; ventral rim straight medially. Parameres narrow, quite curved, with basal portions apically black, gently curved; apex of each paramere somewhat rounded, not sharpened and touching each other (Fig. 11E).
Female (Fig. 11A): Measurements: $(\mathrm{n}=1)$ Total length: 5.72; width: 3.56; head length: 1.20 ; width: 1.65 ; interocular space: 1.11 ; antennal segment lengths, I: 0.36; II: 0.36; III: 0.42; IV: missing; V: missing; pronotum length: 1.44; width at base: 3.57 ; scutellum length: 1.71 ; width: 2.17 .

Similar to male in coloration. Pendergrast's organs present, large, well-developed, slightly darker than rest of the segment (Fig. 11C). Genitalia: First gonocoxae elongate, wide, surfaces rugose; second gonocoxae small, each gonocoxite nearly triangular posteriorly; paratergites 8 narrow, short, widely rounded posteriorly; paratergites 9 subtriangular (Fig. 11D).

Etymology. The specific name comes from " $k o l$ $l a$ " the ethnic group that inhabits the area where this species was found.

Distribution. ARGENTINA: Salta (Fig. 10).

Host plant. Unknown.

Discussion. This species differs from $H$. johnpolhemi, its closest relative, by its smaller size and different coloration, especially by the presence of two dark spots on the base of the scutellum (in $H$. johnpolhemi, there is a continuous dark band on the base of the scutellum).

\section{CONCLUSIONS}

\section{Some biological and ecological aspects about this complex}




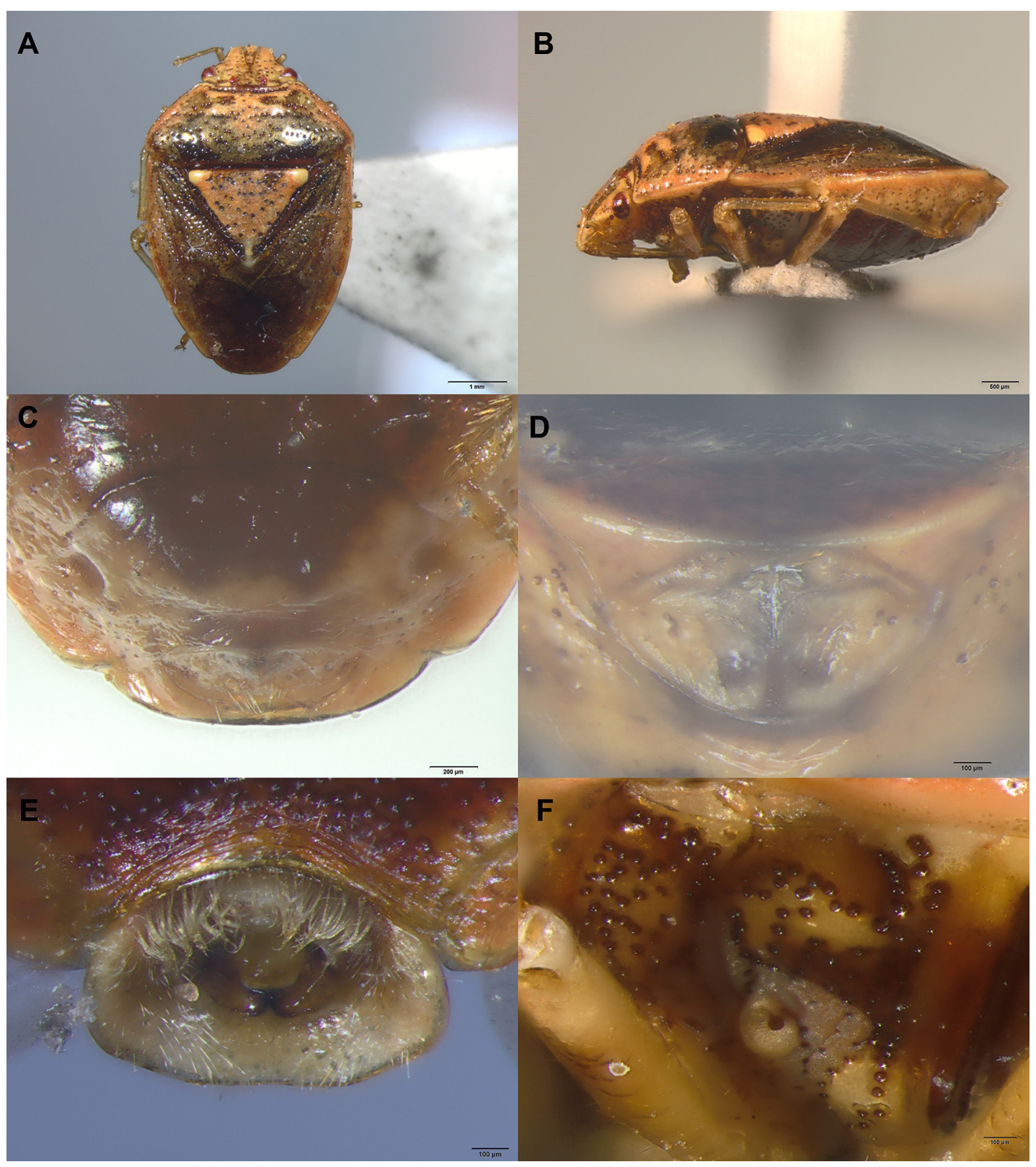

Fig. 11. Hellica kolla sp. nov. A. Female, dorsal view. B. Female, lateral view. C. Female, abdomen showing genitalia ventral view. D. Female, genitalia caudal view. E. Male, pygophore dorsal view. F. Metapleura.

Regarding the presence or absence of the Pendergrast's organs, we provide a transcription of the text published by Fischer (2006), in which he comments on the relationship of its absence with the maternal care observed in the genus Elasmucha Stål; similar inferences might be possible for other related genera lacking this organ: "Pendergrast's organs are totally absent in species of the genera Aga- medes, Bebaeus, Catadipson, Elasmucha, Ibocoris, Mahea, Phorbanta, Proctophantasta, and Uhlunga. The absence of Pendergrast's organs in Elasmucha-species correlates with the presence of maternal care, which the females of these species perform. The females guard their eggs and nymphs. Catadipson, Ibocoris, Proctophantasta, and Uhlunga are closely related to Elasmucha." Tsai et al. (2015) also stated: "Considering the 
strong correlation between a morphological and a behavioral trait, maternal care can be expected to occur in other genera of the family." Considering these studies, we believe that members of the genus Epactiohellica gen. nov. may exhibit maternal care, something that we have not been able to corroborate yet, as we did not find populations in our field trips during the summer 2018-19.

Coloration. Species of this complex have a cryptic homochromy; that is, their coloration allows them to be camouflaged in the environment. Selective pressure for this may be due to the fact that members of the Cyperaceae develop in full sun exposure, a habitat which may make these bugs more vulnerable to predators (Fig. $13 \mathrm{~A}, \mathrm{~B}, \mathrm{D})$.

The eggs of Hellicoides johni were deposited on the involucral leaf of the inflorescence of Scirpus giganteus. The number of eggs in the observed egg mass was 14, of which eight hatched (the white ones) and the rest varied in coloration from brown to light brown, with a single silver coloured egg (Fig. 13E).

Regarding the observations on eggs of Ditomotarsus hyadesi Signoret made by Carvajal \& Faúndez (2015), we agree that $H$. johni eggs may have different colours similar to $D$. hyadesi, but they say: "One female can only lay eggs of one colour during her lifetime." We observed more than one colour in the same egg mass. Another interesting coincidence is that they also state: "Collecting the eggs was a difficult work because they jump with the contact of the paint brush." We took pictures of the eggs in the field, and then brought the plant samples to the laboratory. We were unable to find the egg masses in the laboratory; this may be because they "jumped" from the Scirpus involucral leaf before we could secure them.

\section{Previous knowledge and hypothesis.}

One of the primary objectives of this study was to determine the host plants of the species of this genus-complex. South American genera and species of Acanthosomatidae are distributed mostly along the Andes Mountains and south of the Andean Region (Morrone, 2001) where they have become most diversified. In this region, acanthosomatids are nearly always associated with the Nothofagus (Nothofagaceae: Fagales) or at least with the forests of Nothofagus. Genera and species of the Hellica complex are distributed mostly in southeastern South America, in the Neotropical Region, "Chaqueña" Subregion, Chaco and Pampa provinces (Morrone, 2001);
Nothofagus is not found in this region.

Prior to this investigation, several possible host plant associations were recorded in the literature. For example, Berg (1884), repeated by Bosq (1937) reported "Banasa pulchella", as occurring on "Calabaza" or "Yeruá" Lagenaria vulgaris (L.) Ser. (Cucurbitaceae). This plant name was updated by Dellapé (2016) as L. siceraria (Molina) Standl. Additionally, Di Iorio \& Turienzo (2015) mentioned this species as occurring on Solanum sp. (Solanaceae) in Buenos Aires. Grazia \& Schwertner (2015), among other plant families, indicated that some species of Acanthosomatidae frequent species of Cyperaceae.

In accord with this information, in the summer of 2018-19, we began to survey potential host plants for the acanthosomatid species known to occur in the argentine province of Buenos Aires. The authors had already collected several of these species (including Hellica kolla sp. nov. from northern Argentina). It became apparent that the collected specimens were always found near water: Hellicoides johni on the banks of the Parana and De La Plata rivers, Epactiohellica farinai on the edge of the Atlantic Sea, Alloeohellica faundezi on the edge of the De Los Padres lagoon, at the base of the De Los Padres hills (near Mar del Plata) and Hellica nitida, the most widely distributed species, always near watercourses or lagoons in the eastern part of Argentina, Uruguay and southern Brazil.

In addition, the first author recalled having collected species of Hellica on Cyperaceae of the type with "spikelets arranged in umbels" (Cabrera \& Zardini, 1978), probably belonging in either Cyperus and/or Scirpus. The particular coloration of the species of both acanthosomatid genera, which mimics perfectly with the inflorescences of the Cyperaceae (Figs. 13A and D), supported the hypothesis that they might be found on these plants.

Interestingly, there are almost never long series of specimens of the studied acanthosomatid species; that is, they are not found in large numbers in collections (see Haglund 1868; Berg 1884; Mendonça Jr et al. 2009; Carpintero \& De Biase 2011; Di Iorio \& Turienzo 2015; Dellapé 2016). Despite having been found many times and in many localities, species of this generacomplex have never been collected abundantly, perhaps because they are probably found in small populations in nature. In addition, nymphs had not been mentioned of any species of Hellica, except those briefly described by Berg (1884). 


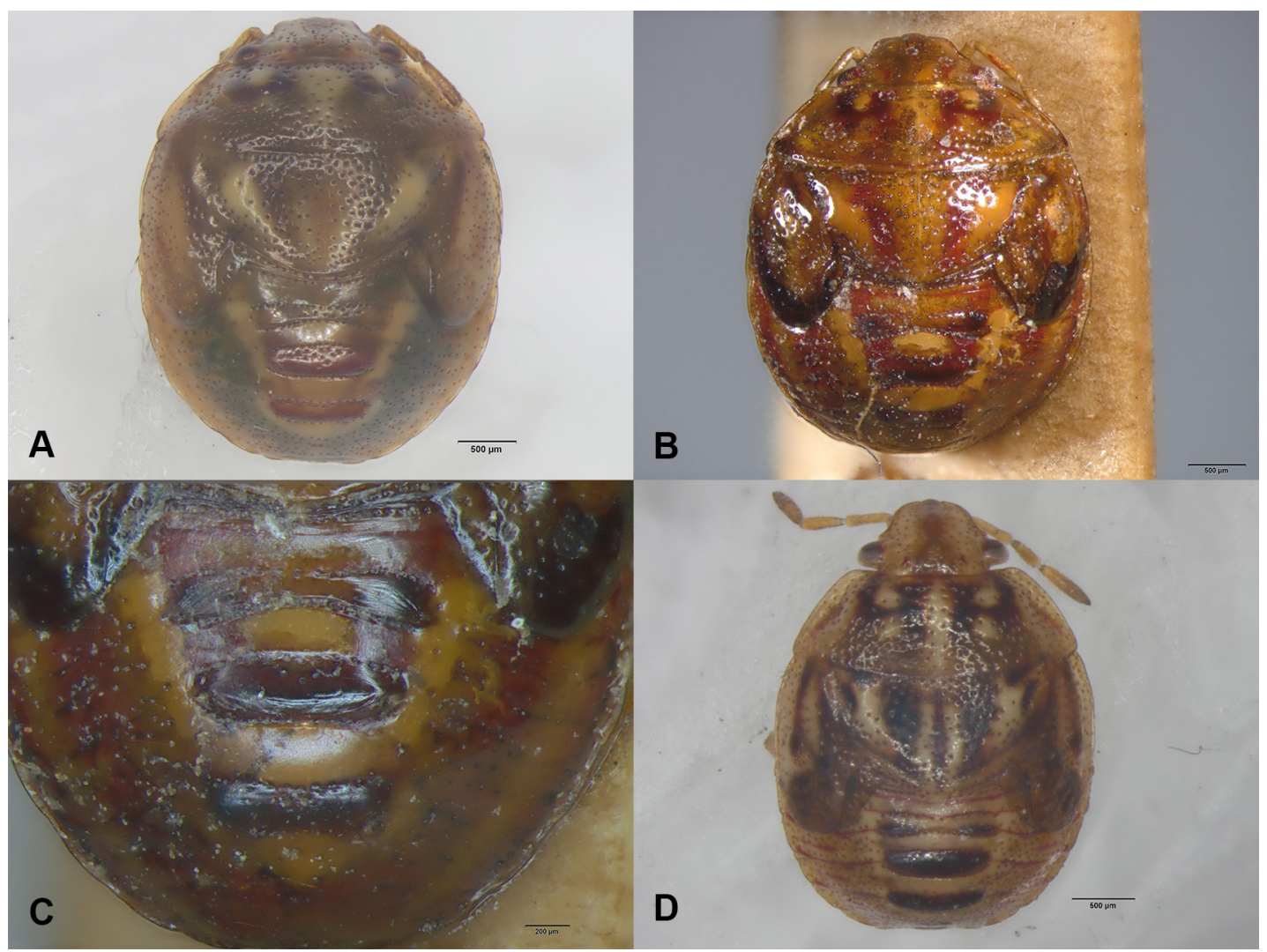

Fig. 12. Nymphs V. A. H. nitida. A fresh specimen. B. H. nitida. From the old museum collection (Berg). C. Detail of dorso-abdominal scent glands. D. H. johni.

\section{Results of our research.}

After reviewing the above information from the literature, the authors suspected that some, or perhaps all, species in the Hellica complex may be found on species in the family Cyperaceae.

Another noteworthy aspect of the field observations is the monospecificity of the studied species of Hellica's complex, which is probably a common characteristic of all their species. To corroborate this theory we must mention that in the species that we have been able to observe (H. nitida and H. johni) in natural populations, they always were found cohabiting adults and nymphs, and their eggs were also found with them. It is also noteworthy that in this study, the populations per plant (inflorescence) contained from three to seven specimens per plant, depending on the species considered.

In the case of Hellica nitida, the most widely distributed species of this complex, specimens are nearly always found on Cyperus eragrostis eragrostis (Cyperaceae) which is very common in northern Buenos Aires. It is adventitious, and can easily be found in the city. It is very common in or near the sidewalks of the cities around the city of Buenos Aires. Hellica nitida, however, is never found on this plant in the city. We believe this is due to the Cyperus populations in the city grows especially in the sidewalks of the streets and in the corners, where there is more humidity. There, they are annually cut. It appears that Hellica nitida, for development, requires natural populations of Cyperus eragrostis eragrostis, populations that are present year after year without human interference.

As for Scirpus giganteus (Cyperaceae) on which Hellicoides johni was found, it has a more restricted distribution being confined to the system of the Paraná (and Paraguay)-Uruguay-de la Plata rivers. For this reason, this acanthosomatid has only been found on the banks of these rivers.

Superimposing the known distributions of the bugs with that known for their host plant, it can be seen that their distributions coincide, and further localities can be identified where the bugs may potentially occur. Furthermore, by an- 


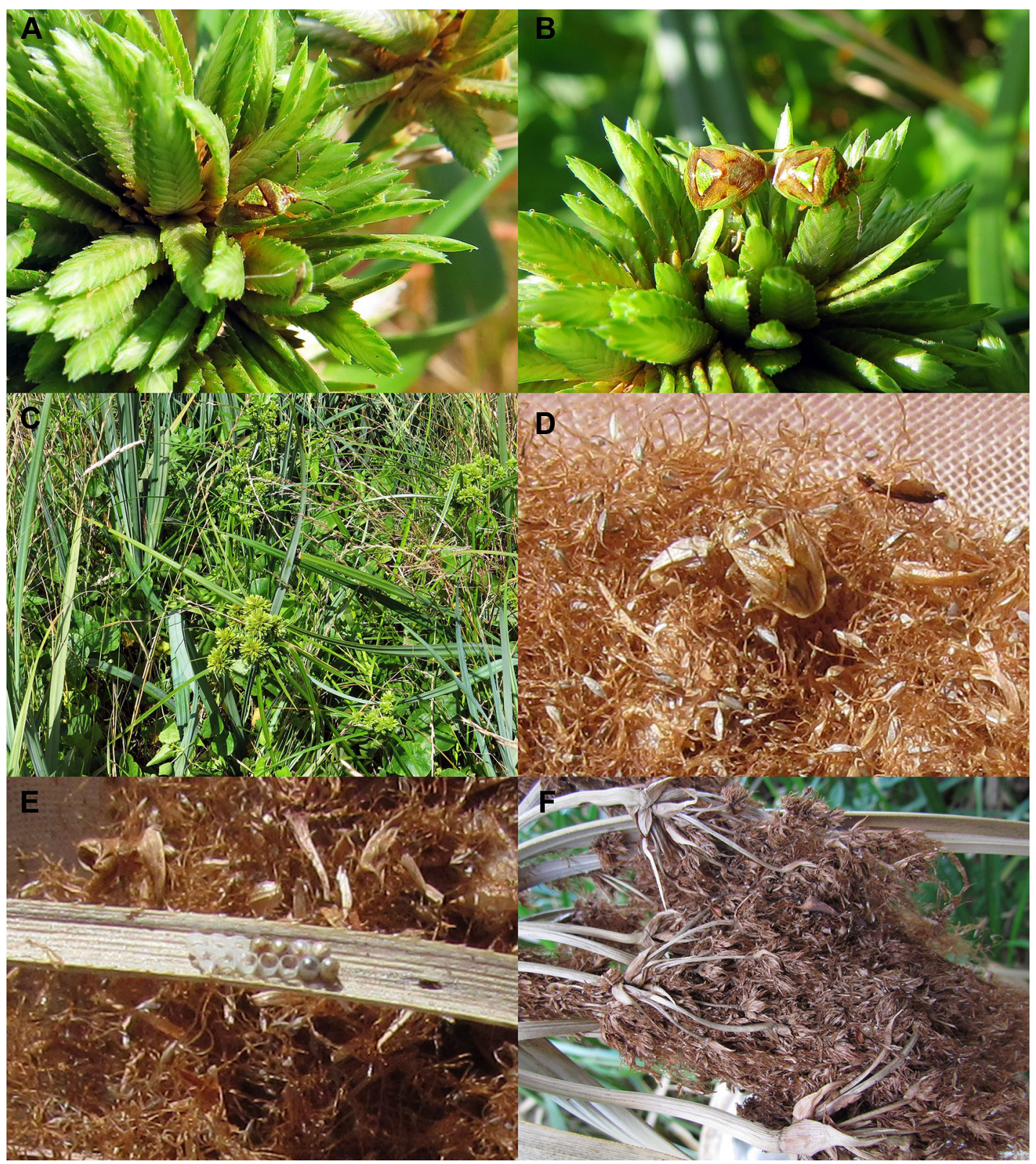

Fig. 13. A. H. nitida. Note the cryptic coloration on the host plant. B. H. nitida. Copulating. C. Cyperus eragrostis eragrostis in "Reserva Laguna de los Padres" (Buenos Aires) (A, B, C, photographs courtesy J. L. Farina). D. $H$. johni. Note the cryptic coloration on the host plant. E. H. johni. Eggs. F. Scirpus giganteus. Inflorescence. D, E and F in "Reserva Ecológica Costanera Sur" (Buenos Aires city).

alyzing the distributions of all species of Cyperaceae known from the province of Buenos Aires, we were able to hypothesize that Hellicoides johni probably occurred on Scirpus giganteus, a fact which was corroborated from the field work in this study.
It may be of interest to the reader to review some characteristics of the host plants. The following has been extracted from the web page of the Darwinion Institute, "Flora del Conosur" (http://www2.darwin.edu.ar/Proyectos/FloraArgentina/DetalleEspecie.asp?) 


\section{Cyperus eragrostis Lam. var. eragrostis} (Fig. 13C)

Habit: Perennial herb.

Status: Native.

Elevation (m.a.s.l.): Minimun height $=0$ -

Maximum height $=2400$.

Distribution: ARGENTINA (Buenos Aires, Catamarca, Córdoba, Corrientes, CABA, Entre Ríos, Formosa, La Pampa, La Rioja, Mendoza, Misiones, Río Negro, Salta, Santa Fe, San Juan, San Luis, Tucumán).

Countries bordering: BRAZIL (Parana, Rio Grande Do Sul, Santa Catarina); CHILE (Valparaíso, Coquimbo, Reg. Metropolitana, Cautín, Araucanía, Concepción, Bío-Bío, Isla de Pascua); URUGUAY (Artigas, Canelones, Cerro Largo, Colonia, Flores, Florida, Maldonado,
Montevideo, Paysandú, Río Negro, Rivera, Rocha, Salto, San José, Soriano).

\section{Scirpus giganteus Kunth}

(Fig. 13F)

Habit: Perennial palustre herb.

Status: Endemic.

Elevation (m.a.s.l.): Minimun height $=0$ -

Maximum height $=600$.

Distribution: ARGENTINA (Buenos Aires, Chaco, Corrientes, CABA, Entre Ríos, Formosa). Countries bordering: BRAZIL (Rio Grande Do Sul, Santa Catarina); PARAGUAY (Cordillera, Paraguarí); URUGUAY (Canelones, Colonia, Flores, Florida, Montevideo, Río Negro, Rocha, San José, Soriano).nda de la f

\section{Key of the genera and species of this genus-complex}

(Modified from Froeschner, 2000; Kumar, 1974; and Rolston \& Kumar, 1974)

We start the key by comparing the Hellica complex with genus Sinopla, which we consider to be the genus most closely related to this complex.

1. Species more than $7.5 \mathrm{~mm}$ long. Paraclypei clearly surpassing anteclypeus, dehiscent; mesosternum with weak, medial longitudinal carina; antennal segment I surpassing apex of head; pronotum with humeral angle projecting laterally as a distinct but short acute angle

\section{SINOPLA Signoret}

- Species $5.5 \mathrm{~mm}$ long or less (only Hellica johnpolhemi sometimes reaches 7mm). Anteclypeus subequal to or slightly longer than paraclypei (Fig. 5); mesosternum without medial, longitudinal carina (Fig. 3); antennal segment I not or just reaching apex of head; pronotum with humeral angle evenly rounded, not forming acute angle.

(HELLICA complex) 2

2. All antennal segments short, of subequal length (Fig. 2A, B); Pendergrast's organs in females absent (Fig. 3); bucculae broad, in lateral view obscuring nearly entire width of labial segment I

EPACTIOHELLICA gen. nov. E. farinai sp. nov.

- Antennae longer, with all segments of different lengths (Figs. 1, 8); Pendergrast's organs in females always present (Fig. 3); bucculae narrow, in lateral view obscuring less than half the width of labial segment I.

3. Hemelytral membranes long, distinctly exceeding beyond apex of abdomen (Fig. 4A); labium and tibiae ventrally covered by long, erect hairs, which are longer than broadness of segments (Fig. $5 \mathrm{D}, \mathrm{E})$; eyes relatively large (Fig. 5B) ALLOEOHELLICA gen. nov. A. faundezi sp. nov.

- Hemelytral membranes at most, slightly surpassing apex of abdomen (Figs. 8A, B); labium and tibiae ventrally covered by shorter hairs, their length not greater than half the tbroadness of segments; eyes relatively small (Fig. 5C, D)

4. Paraclypei nearly reaching apex of anteclypeus, weakly but noticeably depressed subapically; anteclypeus with lateral margins parallel; antennal segment II longer than third (Fig. 5D) .HELLICOIDES gen. nov. H. johni Froeschner

- Anteclypeus weakly but noticeably surpassing apices of paraclypei, weakly tumid, not depressed subapically; anteclypeus widening markedly towards its apex; antennal segment II shorter than third (Fig. 5C) .HELLICA Stål 5 
5. Antennal segment II subequal in length to segment I; dorsal coloration mostly brownish-orange to yellowish-orange with some darker areas (Fig. 11) H. kolla sp. nov.

- Antennal segment II, 25-50\% longer than segment I; dorsal coloration dark or light brown and yellow (in dried specimens) or green (in living specimens) (Figs. 1, 8)

6. Length usually greater than $6 \mathrm{~mm}$; male: Genital capsule with apical margin weakly, but distinctly broadly bilobed on middle third, its dorsal setae scattered; female: 3rd gonocoxa laterally overlapping end of 2nd gonocoxa and in contact with basal genital plate (Fig. 9)

H. johnpolhemi Froeschner

- Length usually less than $6 \mathrm{~mm}$; male: Genital capsule with apical margin not bilobed in middle third, its dorsal setae arranged in groups; female: $3 \mathrm{rd}$ and 2 nd gonocoxae exposed to lateral ends (Fig. 8) H. nitida Haglund

\section{ACKNOWLEDGEMENTS}

Special thanks to Dr María del C. Coscarón from the Museum of La Plata and Dr. David A. Rider from the Entomology Department, School of Natural Resource Sciences, North Dakota State University (USA), for his kind and valuable contribution to this manuscript. To Juan L. Farina, head of the entomological collection of the Municipal $\mathrm{Mu}$ seum of Natural Sciences "Lorenzo Scaglia" of Mar del Plata (Buenos Aires, Argentina) for the cession of materials from his area and the photographs of $H$. nitida in its host plant. To Dr. Horacio Sirolli and Lic. Lorena Zapata from the Conservation and Monitoring Sector of the "Reserva Ecológica Costanera Sur" (RECS) and to Mr. Marcelo Raina, head of the Department of Rangers of the "Reserva Integral Laguna de Los Padres" (RILAPA) for their collaboration during our field trips. To the CONICET for his support of this research.

\section{BIBLIOGRAPHY}

Bachmann A.O. 1999. Catálogo de los tipos de Heteroptera (Insecta) conservados en el Museo Argentino de Ciencias Naturales. Revista del Museo Argentino de Ciencias Naturales, nueva serie 1(2): 191-230.

Berg C. 1884. Addenda et Emendanda ad Hemiptera Argentina. Anales de la Sociedad Científica Argentina 17: 97-176.

Bosq J.M. 1937. Lista preliminar de los Hemípteros (Heterópteros), especialmente relacionados con la agricultura nacional. Revista de la Sociedad Entomológica Argentina 9: 111-134.

Brown R.W. 1985. Composition of Scientific Words. Reprint of the 1956 revised edition (from 1954, original ed.). Smithsonian Institution Press (Ed.). Washington, D.C. (U.S.A.) 882 pp.

Cabrera A.L. \& E.M. Zardini. 1978. Manual de la flora de los alrededores de Buenos Aires. Ed. ACME, Ciudad Autónoma de Buenos Aires, Argentina. 755 pp.
Carpintero D.L., S. De Biase \& S. Konopko. 2014. Los Heteroptera (Hemiptera) de la Reserva Costanera Sur. Revista del Museo Argentino de Ciencias Naturales (nueva serie) 16(1): 67-80.

Carpintero D.L., S. De Biase \& S. Konopko. 2015. Heteroptera del Delta. In: Delta: Naturaleza, conservación y patrimonio cultural. (Editor José Athor), Fundación de Historia Natural "Félix de Azara". Buenos Aires, Argentina. Pages 257-290.

Carpintero D.L. \& S. De Biase. 2011. Los Hemiptera Heteroptera de la Isla Martín García (Buenos Aires, Argentina). Revista Historia Natural 1(2): 27 47.

Carvajal M.A. \& E.I. Faúndez. 2015. Revalidation of Ditomotarsus hyadesi Signoret, 1885 stat. rest. (Hemiptera: Heteroptera: Acanthosomatidae) with notes on its Natural History. Biodiversity and Natural History 1: 18-25.

Carvajal M.A., E.I. Faúndez \& D.A. Rider. 2017. Rediscovery of Pseudosinopla canaliculus (Reed, 1898) (Hemiptera: Heteroptera: Acanthosomatidae) with comments on its tribal classification and biogeography of South American Blaudusini. Zootaxa 4317(1): 185-190.

Coscarón M.C. 2017. A catalogue of the Heteroptera (Hemiptera) or true bugs of Argentina. Zootaxa 4295(1): 1-432 (Monograph).

Coscarón M.C., C. Basset \& N. Lopez. 2015. Types of true bugs (Insecta, Hemiptera, Heteroptera) deposited in the Museo de La Plata, Argentina. Zootaxa 3977(1): 1-101 (Monograph).

Dellapé G. 2016. Sinopsis de los Acanthosomatidae (Heteroptera) de Argentina. Revista de la Sociedad Entomológica Argentina 75(1-2): 81-90.

Di Iorio O. \& P. Turienzo. 2015. Campo de Mayo: un área natural histórica en los alrededores de la ciudad de Buenos Aires, Argentina, que merece ser declarada reserva natural. Revista del Museo Argentino de Ciencias Naturales, nueva serie 17(1): 13-42.

Faúndez E.I., M.A. Carvajal \& D.A. Rider. 2014. Archaeoditomotarsus crassitylus, gen. and sp. nov. (Hemiptera: Heteroptera: Acanthosomatidae) from Chile. Zootaxa 3860(1): 87-91.

Fischer C. 2006. The biological context and evolution of Pendergrast's Organs of Acanthosomatidae 
(Heteroptera, Pentatomoidea). Denisia 19, zugleich Kataloge der OÖ. Landesmuseen (Neue Serie) 50: 1041-1054.

Froeschner R.C. (1999) 2000. Revision of the South American genus Hellica Stål (Heteroptera: Acanthosomatidae). Journal of the New York Entomological Society 107: 164-170.

Grazia J. \& C.F. Schwertner. 2015. Acanthosomatidae. In: "Biodiversidad de Artrópodos Argentinos" Vol. III, cap. 30. pp. 399-402. (Claps, Debandi \& Roig Juñent, eds.). 544 pp. SEA, San Miguel de Tucumán, Argentina.

Haglund C.J.E. 1868. Hemiptera Nova. Stettiner Entomologische Zeitung 29: 150-163.

Instituto de Botánica Darwinion. Flora del Conosur. Catálogo de las Plantas Vasculares. http://www2. darwin.edu.ar/Proyectos/FloraArgentina/DetalleEspecie.asp?

Kumar R. 1974. A revision of world Acanthosomatidae (Heteroptera: Pentatomoidea): Keys to and descriptions of subfamilies, tribes and genera, with designation of types. Australian Journal of Zoology, Supplementary Series 34: 1-60.

Martinez P., P.M. Dellape, M.C. Coscaron \& H. Giganti. 2003 (2004). Immature stages of Sinopla perpunctatus (Heteroptera: Acanthosomatidae) from Argentina. Entomological News 14(3): 147-151.

Mendonça Jr. M.S., C.F. Schwertner \& J. Grazia. 2009. Diversity of Pentatomoidea (Hemiptera) in riparian forests in southern Brazil: taller forests, more bugs. Revista Brasileira de Entomología 53(1): 121-127.

Morrone J.J. 2001. Biogeografía de América Latina y el Caribe. Manuales \& Tesis. Sociedad Entomológica Aragonesa 3: 1-150.

Pennington M.S. 1920. Lista de los Hemípteros Heterópteros de la República Argentina. (Impreso por el autor en imprenta de calle Brasil 1045, Buenos Aires). 47 pp.
Pirán A.A. 1948. Contribución al conocimiento de la dispersión geográfica de los Hemípteros neotropicales. Acta Zoológica Lilloana 5: 5-17.

Quintanilla R.H., A.E. Margheritis \& H.F. Rizzo. 1976. Catálogo de los Hemípteros hallados en la Provincia de Corrientes (Arg.). Revista de la Sociedad Entomológica Argentina 35(1-4): 115-133.

Rolston L.H. \& R. Kumar. 1974. Two new genera and two new species of Acanthosomatidae (Hemiptera) from South America, with a key to the genera of the Western Hemisphere. Journal of the New York entomological Society 82(4): 271-278.

Ruffinelli A. \& A.A. Pirán. 1959. Hemípteros heterópteros del Uruguay. Boletín de la Facultad de Agronomía de Montevideo, Uruguay 51: 1-60.

Stål C. 1868. Bidrag till Hemipterernas Systematik. Öfversigt af Kongliga Svenska Vetenskaps-Akademiens Förhandlingar 24: 491-560.

Thomas D.B. \& T.R. Yonke. 1990. Review of the Genus Banasa (Hemiptera: Pentatomidae) in South America. Annals of the Entomological Society of America 83(4): 657-688.

Tsai J.F., S. Kudo \& K. Yoshizawa. 2015. Maternal care in Acanthosomatinae (Insecta: Heteroptera: Acanthosomatidae) correlated evolution with morphological change. BMC Evolutionary Biology 15: 258-270.

Types of Heteroptera. Species-list. Swedish Museum of Natural History. Hellica nitida http://www2.nrm. se/en/het_nrm/n/hellica_nitida.html

Viana M.J. \& G.J. Williner. 1972 . Evaluación de la fauna entomológica y aracnológica de las provincias cuyanas. Primera comunicación. Acta Scientifica, serie Entomología, 5: 1-29.

Viana M.J. \& G.J. Williner. 1978. Evaluación de la fauna entomológica y aracnológica de las provincias centrales y cuyanas (cuarta comunicación). Acta Scientifica, serie Entomología 11: 1-77.

Doi: 10.22179/REVMACN.21.632

Recibido: 2-IV-2019

Aceptado: 26-X-2019 
